INTERNATIONAL FOOD POLICY

RESEARCH INSTITUTE

sustainable solutions for ending hunger and poverty

A member of the CGIAR consortium

IFPRI Discussion Paper 01254

March 2013

\title{
A Partial Equilibrium Model of the Malawi Maize Commodity Market
}

\author{
Mariam A. T. J. Mapila \\ Johann F. Kirsten \\ Ferdinand Meyer \\ Henry Kankwamba
}

Development Strategy and Governance Division 


\section{INTERNATIONAL FOOD POLICY RESEARCH INSTITUTE}

The International Food Policy Research Institute (IFPRI) was established in 1975 to identify and analyze national and international strategies and policies for meeting the food needs of the developing world on a sustainable basis, with particular emphasis on low-income countries and on the poorer groups in those countries. IFPRI is a member of the CGIAR Consortium.

\section{PARTNERS AND CONTRIBUTORS}

IFPRI gratefully acknowledges the generous unrestricted funding from Australia, Canada, China, Denmark, Finland, France, Germany, India, Ireland, Italy, Japan, the Netherlands, Norway, the Philippines, South Africa, Sweden, Switzerland, the United Kingdom, the United States, and the World Bank.

\section{AUTHORS}

Mariam A. T. J. Mapila, International Food Policy Research Institute

Postdoctoral Fellow, Development Strategy and Governance Division

m.mapila@cgiar.org

Johann F. Kirsten, University of Pretoria

Head of Department, Department of Agricultural Economics, Extension and Rural Development

Ferdinard Meyer, University of Pretoria

Team Leader, Bureau for Food and Agricultural Policy

Henry Kankwamba, Lilongwe University of Agriculture and Natural Resources

Lecturer, Department of Agricultural and Applied Economics

Notices

IFPRI Discussion Papers contain preliminary material and research results. They have been peer reviewed, but have not been subject to a formal external review via IFPRI's Publications Review Committee. They are circulated in order to stimulate discussion and critical comment; any opinions expressed are those of the author(s) and do not necessarily reflect the policies or opinions of IFPRI.

Copyright 2013 International Food Policy Research Institute. All rights reserved. Sections of this material may be reproduced for personal and not-for-profit use without the express written permission of but with acknowledgment to IFPRI. To reproduce the material contained herein for profit or commercial use requires express written permission. To obtain permission, contact the Communications Division at ifpri-copyright@cgiar.org. 


\section{Contents}

Abstract $\quad$ V

Acknowledgments $\quad$ vi

1. Introduction 1

2. Data 2

3. The Dynamics of Maize Price Formation in Malawi 4

4. Model Specification 12

5. Conclusion and Model Limitations 23

Appendix A: Various Statistical Test Results 24

Appendix B: Historical Background of ADMARC Reforms and Impacts on Various Stakeholders in Malawi $\quad 29$

$\begin{array}{ll}\text { References } & 30\end{array}$ 


\section{Tables}

2.1-Average statistics for Malawi maize subsector, 1989/90-2010/2011 2

3.1 - Smallholder maize production and marketing, 2004/05 versus 2010/11 5

3.2-Pairwise correlations between SAFEX, ADMARC, and local maize prices 7

4.1-Single equation validation: Fitted equations with robustness tests 20

A.1-Augmented Dickey-Fuller test results, maize-sector data 24

A.2-Augmented Dickey-Fuller test results, local market maize prices 24

A.3-Johansen cointegration test results 25

A.4-Granger causality test results 26

A.5-Coefficient correlation test results (between local market prices) 27

B.1-Historical timeline of ADMARC reforms in Malawi 29

B.2-Impact of the ADMARC reforms on different stakeholders 29

\section{Figures}

3.1-Maize price co-movements in selected markets $\quad 8$

3.2-Import and export parity price analysis $\quad 10$

4.1-Structure of the Malawi maize market 19 


\begin{abstract}
This paper presents a model of the Malawi maize commodity market that is developed for use as a policy analysis tool. The model captures national and local maize market dynamics and the linkages existing within the maize market in the country. This research has been undertaken in order to provide policy makers with a robust tool which can be used to simulate the impact of policy changes on markets and households. Such a tool ensures the availability of evidence for informing food and agricultural policies. The model is a multiequation partial equilibrium model of the national maize market in Malawi. It is developed and linked in a top-down unidirectional manner to the local maize economy via a price linkage equation. A nonbehavioral arithmetic microaccounting approach is used to estimate rural household incomes that are linked to the local economy, through which macroeconomic-level maize price changes transmit. The model can be used as a tool for analyzing the impacts of macroeconomic and agricultural policy changes on the maize industry as well as on rural households that rely on maize. The novelty of the model is that it takes into account the interrelationships between farm/household, local-economy, and national maize market prices, as well as economic theory and existing empirical evidence, to build a framework that is capable of linking to the macroeconomy rural subsistence households that are traditionally deemed to have few or no backward and forward linkages.
\end{abstract}

\title{
Keywords: impact evaluation, simulation, time-series modeling, commodity markets, southern Africa, Africa south of the Sahara, rural household
}




\section{ACKNOWLEDGMENTS}

The authors acknowledge the financial support from the Bureau for Food and Agriculture Policy (BFAP) of the University of Pretoria and the BACHOMA (Malawi) family trust fund. 


\section{INTRODUCTION}

Maize remains the main staple food crop for Malawi as well as for many other countries in southern Africa. Improving the performance of the sector thus remains a key national priority for many governments in the region-not only for overall agricultural and economic development but also as a strategy for overcoming rampant hunger and food insecurity. This paper provides the details of a partial equilibrium model of the Malawi maize market. The model is developed in order to improve the understanding of the functioning and dynamics of maize markets in the country. It is a tool that can be used to better understand the impact of different policies on maize production and marketing as well as on rural households that rely heavily on maize. In addition, the model is linked to regional markets in southern Africa and thus can be used to better analyze regional maize trade, food security, and intercountry dependence. Understanding regional dynamics is essential for the southern African region, which has moved toward greater regional integration through the establishment of a free trade area.

There are numerous studies of the dynamics of price, trade, markets, and input use for the maizebased farming system and industry in Malawi (Chirwa 2005, 2009, 2010b; Jayne et al. 2010; Minot 2010, 2011; Chibwana, Fisher, and Shively 2012; Ellis and Manda 2012). The vast literature uses different quantitative and qualitative tools to analyze the Malawi maize subsector, but to the authors' knowledge there are no studies that have developed a partial equilibrium framework. Partial equilibrium frameworks are used widely in modeling commodity markets and trade. They are highly favored for developingcountry economies because they are capable of effectively estimating the general effects of agricultural policy changes in the presence of weak linkages between commodities and their supplier or output sectors (Perali 2003). Such weak linkages are common in many developing economies, including that of Malawi (Chirwa 2010a). In addition, partial equilibrium modeling is computationally less complex than other types of models, such as economywide models. However, they still enable the simulation of the impacts of policy changes over time, thus allowing dynamism in the analysis of commodity markets and trade.

In the next section we present in brief a description of the data that have been used to develop the model; this is followed by a section that aims to provide insight into the dynamics of price formation in the Malawi maize market. This analysis will inform the development of a partial equilibrium maize model, which is then described in detail in Section 4. Section 5 concludes. Simulations of the impacts of policy changes on the maize commodity market and on rural household incomes have been conducted with earlier versions of this model and are presented separately from this paper. 


\section{DATA}

Time series data from the 1989/90 agricultural season to the 2010/11 agricultural season were used to estimate single equations, which were in turn used to build the partial equilibrium framework. Due to lack of a single comprehensive source, data were obtained from various sources, including the World Bank; the Food and Agriculture Organization (FAO) of the United Nations; the United Nations Conference on Trade and Development; and the Malawi Ministry of Agriculture and Food Security, National Statistical Office, and Department of Meteorological Services and Climate Change. Data from international databases were validated with industry players and government experts to ensure accuracy.

Table 2.1 presents the mean values for area of maize planted, maize yields, domestic maize production, domestic maize consumption, per capita maize consumption, national producer price of maize, imports, and exports for the period 1989/90 to 2010/11. The national producer price of maize is defended by the public agricultural marketing board called the Agricultural Development and Marketing Corporation (ADMARC). This paper therefore refers to the price that prevails in all marketing board markets as the ADMARC price. Results of the augmented Dickey-Fuller test for nonstationarity of the data are given in Table A.1 (Appendix A).

Table 2.1—Average statistics for Malawi maize subsector, 1989/90-2010/2011

\begin{tabular}{lrrrr}
\hline & $\mathbf{1 9 8 8 / 8 9 -}$ & $\mathbf{1 9 9 3 / 9 4 -}$ & $\mathbf{1 9 9 9 / 2 0 0 0 -}$ & $\mathbf{2 0 0 5 / 0 6 - ~}$ \\
& $\mathbf{1 9 9 2 / 9 3}$ & $\mathbf{1 9 9 8 / 9 9}$ & $\mathbf{2 0 0 4 / 0 5}$ & $\mathbf{2 0 1 0 / 1 1}$ \\
\hline Area planted (in '000 ha) & $1,340.32$ & $1,248.80$ & $1,451.18$ & $1,665.49$ \\
Yield (mt/ha) & 1.07 & 1.18 & 1.15 & 1.97 \\
Domestic production (in '000 mt) & $1,163.34$ & $1,305.75$ & $1,316.54$ & $2,505.53$ \\
Domestic consumption (in '000 mt) & $1,476.38$ & $1,545.30$ & $1,593.32$ & $1,881.52$ \\
Maize imports (in '000 mt) & 313.41 & 242.17 & 315.82 & 83.72 \\
Maize exports (in '000 mt) & 0.26 & 2.64 & 0.78 & 35.19 \\
Ending stocks (in '000 mt) & 2.12 & 2.30 & 2.28 & 4.711 \\
Population (millions) & 9.15 & 9.95 & 11.3 & 13.27 \\
ADMARC price (US dollars / mt) & 148.78 & 161.43 & 178.84 & 167.32 \\
Food inflation (consumer price index: food) & 6.70 & 31.28 & 163.93 & 387.98 \\
\hline
\end{tabular}

Sources: Malawi National Statistics Office; Malawi Ministry of Agriculture and Food Security, Agricultural Marketing and Information Survey; Malawi Ministry of Agriculture and Food Security, Agricultural Statistics Bulletin.

From Table 2.1 it can be seen that domestic maize production has generally had an increasing trend. However, from the 1993/94 season to the 1998/99 season, average maize production decreased, while from the 1999/2000 season to the 2004/05 season, it stagnated. This is attributed to unfavorable weather conditions and erratic rainfall, which culminated in a severe drought in the 2001/02 cropping season. In the period following 1999/2000-2004/05, average domestic maize production increased by more than 63 percent as a result of the implementation of the Farm Input Subsidy Programme, which was initiated in 2005/06. The trend in domestic production is also reflected in yields of maize, with maize yields, which were increasing at a slow pace in the late 1980s, declining between the 1993/94-1998/99 time period and the 1999/2000-2004/05 period by 2 percent. Favorable weather conditions and government fertilizer policy have also had a positive impact on maize yields in recent years, with average maize yields increasing by more than 40 percent, from $1.15 \mathrm{~kg} /$ ha during the 1999/2000-2004/05 period to almost $2 \mathrm{~kg} / \mathrm{ha}$ in the 2005/06-2010/11 time period.

Domestic maize consumption generally has had an increasing trend since the late 1980s but stagnated between the 1993/94-1998/99 and the 1999/2000-2004/05 time periods. It picked up, however, in the 2005/06-2010/11 period by nearly 15 percent. The steady increase in domestic consumption is attributed to higher domestic production as well as a growing population. Domestic consumption has had an increasing trend despite increases in the domestic price of maize and high food inflation. Acreage 
declined between the 1988/89-1992/92 and the 1993/94-1998/99 time periods. Since the 2005/06 cropping season, however, the acreage allocated to maize has increased steadily. Maize exports and ending stocks have historically been negligible. However, since the 2005/06 cropping season, both exports and ending stocks have increased noticeably. Maize imports have varied over the years, with peaks being observed in time periods of low maize productivity. In recent years, maize imports have declined rapidly, reaching negligible levels in the 2011/12 season. Historically, ADMARC maize prices have had an increasing trend. Since the 2005/06 cropping season, however, ADMARC maize prices have exhibited a downward trend. Changing trends in maize exports, imports, stocks, and prices are attributed to surplus maize production that the country has been having since the introduction of the Farm Input Subsidy Programme in the 2005/06 cropping season.

In summary, since the late 1980s the maize subsector has exhibited consistent increases in production, acreage, consumption, and yields. Increases in production have led to an increase in the ending stocks as well as maize exports, a decrease in imports, and a general decreasing trend in prices. The key drivers of the maize market over this time period have been changing climatic conditions; an increasing population; and government policies, especially the introduction of the Farm Input Subsidy Programme in the 2005/06 cropping season. 


\section{THE DYNAMICS OF MAIZE PRICE FORMATION IN MALAWI}

Understanding the dynamics of price formation is a critical first step in developing a partial equilibrium model because in partial equilibrium modeling, equilibrium is reached through the adjustment of prices until supply equals demand. Prevailing prices in the maize market in Malawi differ depending on the level of the market because most commodity markets in the country can be subdivided into three separate but highly interlinked market levels: the farm- (household-) level market, the local-economy market, and the national market. The section that follows provides insight into the price formation processes at each of these levels but also assesses the nature and direction of the linkages among the three levels for the maize industry. This analysis leads to a better appreciation of the price transmission mechanism among the three price levels, thus allowing for better understanding of the patterns, trends, and relationships governing price formation in the country, which is essential for developing a robust model.

The farm-level market consists of individual rural households that are both producers and consumers of maize. The price prevailing in the farm/household market is the farmgate price, the price at which producers sell to roving traders in their villages and communities, and the price at which farmers sell to each other within a community. In addition, the farmgate price is also the equivalent price at which maize is exchanged for other goods and services within the community.

The second market level, the local-economy market, is focused in rural trading centers across the country and can be seen as a central market for a specific rural locality that comprises several villages and communities. The local-economy market is the nexus of all household economies in a particular rural locality. The price prevailing in the local-economy market is referred to in this paper as the local price. Currently the Ministry of Agriculture and Food Security collects and tracks the weekly price levels in 72 local markets across the country as part of the Agricultural Market Information Survey (AMIS). Two different types of maize trade take place in local markets. First, producers who choose not to sell at the farmgate price sell their maize either to large traders stationed at the local market or to consumers. Second, the roving traders who buy maize at the farmgate price from producers also sell maize to the large traders at the trading center.

Finally, there is the national maize market, which is controlled by the government and in which the ADMARC price prevails. ADMARC depots can be found in some but not all rural trading centers in the country, so producers also have the option of directly selling to ADMARC. In many instances, producers prefer to sell to private traders, who start buying maize from farmers at the outset of the harvest period, while ADMARC takes longer to buy as it awaits the announcement of the official ADMARC selling and buying prices. In many instances, private traders offer a lower price to producers than does ADMARC; however, because producers are strapped for cash, they are unable to store their maize until higher prices prevail in the market.

\section{Understanding Maize Price Formation at Different Market Levels}

The pricing of maize differs at the farm/household level, the local-economy level, and the national level due to the nature and structure of the country and the thriving rural economies that vary spatially across the country. At the farm/household level, the dynamics of maize pricing are far more complex than at the national or local market level, due to the nature of the rural household economy, which is limited by the absence of cash income, and due to the extremely important role that maize plays in the diets and nutritional attainment of many rural households in Malawi. In addition, it is complicated by farmers who are both producers and consumers of maize. Maize is extremely important in Malawi as a crop, more than 90 percent of all households growing it. Table 3.1 shows that from 2004/05 to 2010/11, the percentage of households that grow maize has declined slightly, from 96.4 percent to 90 percent, although this difference is not statistically significant. 
Table 3.1 - Smallholder maize production and marketing, 2004/05 versus 2010/11

\begin{tabular}{|c|c|c|c|c|c|}
\hline & \multicolumn{2}{|c|}{ 2004/05 season } & \multicolumn{2}{|c|}{ 2010/11 season } & \multirow{2}{*}{$\begin{array}{l}\text { Chi-square } \\
\text { statistic }(\rho)\end{array}$} \\
\hline & Yes & No & Yes & No & \\
\hline$\%$ of households that grow maize & 96.40 & 3.60 & 90.0 & 10.0 & 0.53 \\
\hline $\begin{array}{l}\% \text { of households that market maize from own } \\
\text { production }\end{array}$ & 33.55 & 66.45 & 34.93 & 65.07 & 1.08 \\
\hline$\%$ of farmers that use maize in barter & 41.0 & 35.6 & 41.8 & 49.3 & 0.89 \\
\hline
\end{tabular}

Source: Author calculations using data from the Malawi National Agricultural Statistics Office

Note: For all three variables, differences observed between the 2004/05 season and the 2010/11 season are not statistically significant.

Maize is grown mainly for subsistence purposes, with more than 65 percent of households in both the 2004/05 and 2010/11 seasons not selling any of their maize (Table 3.1). Although only one-third of households sell their maize, a large proportion of households (more than 40 percent in both seasons represented), use maize in barter.

At the national level, prices for maize are set by the government based on national annual production estimates, the supply-and-demand structure of the country, welfare considerations for lowincome consumers, and the goal of ensuring a price for smallholder producers that encourages production and reinvestment in the farm. The national producer price of maize governs the purchase and selling price of maize in all government markets that are operated by ADMARC, the public marketing board responsible for buying and selling food crops throughout the country. The national producer price is the same throughout all ADMARC markets in the country regardless of spatial differences in production and availability of maize. The ADMARC maize price is announced through the radio and other communication media at the end of the cropping season. Furthermore, since maize is imported from countries throughout the region (mainly South Africa) in times of food shortage, regional prices of maize also influence the ADMARC maize price. However, since the Malawi maize market is not fully liberalized, the government often uses import and export bans and price controls to buffer the effects of regional and international maize price fluctuations in order to ensure food security, and therefore price transmission is often low.

On the other hand, the local market maize price is the prevailing price in different local markets throughout the country. Ideally, price should be set competitively, depending on the supply-and-demand dynamics as well as the prices of substitutes and complements. In Malawi, this is not the case, as the maize market is uncompetitive, which leads to direct government intervention (Jayne et al. 2010). Government intervention has taken place in many forms in Malawi, with the private sector initially being excluded from the maize trade. Since liberalization of the maize market in 1994, the private sector has played a greater role in the maize trade, but the government still controls the maize trade through price interventions and export bans.

\section{Relationship between National Maize Prices and Local Market Maize Prices}

This study uses cointegration analysis to better understand the relationship between the ADMARC price and local market prices in Malawi. Currently the Ministry of Agriculture and Food Security collects and tracks weekly prices in 72 local markets across the country as part of the AMIS. Only a few markets, however, have complete and consistent data. Therefore this study uses 25 of the 72 local markets to demonstrate the interlinkages between local maize price and the ADMARC market price. It should be noted that all market prices are collected and reported in local currency (Malawi kwacha). In order to facilitate wider applicability of study findings and replicability of the methodology, however, all analysis in this study uses the dollar equivalent based on the annual average exchange rate between the Malawi kwacha and the US dollar, as reported by the Reserve Bank of Malawi. 
As a pretest for cointegration analysis and to determine the degree of stationarity, the augmented Dickey-Fuller (ADF) test was carried out to detect the presence of unit roots. Results show that all the maize price data have ADF statistics that are, in absolute terms, greater than the MacKinnon critical values. This shows that all the maize price data are stationary, as indicated in Table A.2 (Appendix A). Therefore the null hypothesis for nonstationarity for all the series can be rejected at the 5 percent confidence level. Since all the maize prices are stationary, we carried out an analysis of the long-run relationship of maize price data for each of the 25 local markets with the ADMARC maize price, using the Johansen cointegration test to determine whether the maize prices in the local markets are integrated with the ADMARC price. The results, in Table A.3 (Appendix A), show that the ADMARC maize price is cointegrated with all local market prices, since in each case the estimated Johansen trace statistic is greater than the 0.05 critical cut-off value. This result implies that each of the local maize market prices included in the analysis has a long-run equilibrium relationship with the ADMARC maize price.

Further analysis using the Granger causality test shows that the relationship between the ADMARC maize price and the maize price for each of the local markets is one-way in nature. The chisquare test statistic reported in Table A.4 (Appendix A) shows that the ADMARC maize price Grangercauses local market maize prices, and local market maize prices do not Granger-cause the ADMARC maize price. This result implies that the lagged values of the ADMARC price can be used to predict current local market maize prices, but lagged values of local maize prices cannot be used to predict current prices of maize in ADMARC markets. This result is expected, given the nature of the price system in the country. These findings of a one-way Granger causality (no feedback relation from local maize markets to the ADMARC markets) have two key implications. First, despite the existence of thriving rural local market economies, macro-level price changes in the national maize market transmit to rural maize markets. It is through this maize price transmission mechanism that rural farming households are affected by macro-level policy changes, since maize is the main staple food crop for the majority of rural smallholder farmers in the country and many farmers depend on local markets for either marketing any surplus maize production or purchasing maize in times of food scarcity. Second, Goletti and Babu's (1994) radical model of price transmission can apply to the Malawi maize market, in that prices in local maize markets are determined by a combination of the current and past prices of a "central market" and the past prices of the local market itself. In this case, the ADMARC market is the central market. The application of the radical model of price transmission in Malawi may not, however, be able to completely explain all the variation in local maize prices, as the political and geographical division of the country means there may be more than one "central" market arising from the existence of regional centers (in the central, southern, and northern regions), which may create other market networks at the regional level.

Using correlation coefficient analysis to further understand the relationship between local market maize prices and the ADMARC price reveals a strong linear relationship (Table 3.2). This is the case in both price levels and differences (although results in differences indicate a lower degree of correlation). Table 3.2 shows the correlation coefficient measures between prices in 10 selected local markets and both the South African Futures Exchange (SAFEX) white maize price and the ADMARC maize price. It can be seen from the table that, in general terms, the correlation between the ADMARC maize price and local market maize prices is strong, with all markets exhibiting correlation coefficient measures that are greater than 0.54. In addition, for several markets, the correlation with the ADMARC maize prices is statistically significant at the 5 percent level of confidence. This shows that local market prices are moderately and positively associated with the ADMARC maize price. The strength of association of local maize market prices with the SAFEX white maize price, however, is weak and statistically insignificant for all the 10 local markets. The statistical evidence of a positive linear relationship between ADMARC maize prices and local market maize prices implies that the ADMARC price is a key factor in price formation in local markets in Malawi. Despite interregional and intraregional differences that affect maize price formation in different local markets, it is evident from these results that government price policies (which are defended by ADMARC) play a key role in influencing individual local market prices in different markets throughout the country. 
Table 3.2-Pairwise correlations between SAFEX, ADMARC, and local maize prices

\begin{tabular}{lcc}
\hline \multicolumn{1}{c}{ Local market } & SAFEX & ADMARC \\
\hline SAFEX & 1.00 & 0.32 \\
Chitipa & -0.49 & 0.59 \\
Mzuzu & -0.30 & 0.54 \\
Nkhotakota & -0.38 & 0.63 \\
Lilongwe & -0.38 & 0.69 \\
Mitundu & -0.54 & 0.57 \\
Luchenza & -0.42 & 0.66 \\
Mwansambo & -0.23 & 0.54 \\
Mchinji & -0.45 & 0.58 \\
Ntaja & -0.12 & 0.64 \\
Chilinga & -0.32 & 0.85 \\
ADMARC & 0.32 & 1.00 \\
\hline
\end{tabular}

Source: Authors' calculations using data from the Ministry of Agriculture and Food Security's Agricultural Marketing Information Survey.

Since all the local market prices under analysis exhibit a strong linear, positive relationship with the ADMARC maize price in both levels and differences, it is also expected that local market maize prices will have a linear relationship with each other. In order to ascertain this relationship, we carried out correlation analysis for all market prices. These results are given in Table A.5 (Appendix A), where evidence can be seen of a strong linear, positive relationship between maize grain prices in different local markets within the country. These findings imply that the prices of maize in various local markets in different parts of the country are positively associated and have a tendency to move in the same direction. This finding is expected and can be attributed to the results found earlier, which show that all maize prices in Malawi, regardless of geographical location, are influenced positively by the ADMARC price.

Geographical effects on maize grain pricing cannot, however, be completely ruled out because evidence of the influence of regional differences in maize prices is discernible by looking at the strength of correlation between markets in the same region. Markets such as Mzuzu, Chitipa, Karonga, and Rumphi in the northern region; Chimbiya, Mitundu, Lizulu, and Lilongwe in the central region; and Limbe, Sharpe Valley, Ntaja, Zomba, and Nsanje in the southern region exhibit nearly perfect correlation, with correlation coefficient measures of greater than 80 percent in many cases (see Table A.5). Therefore as prices in one market increase, prices in other markets in the same region will also tend to increase. Despite this phenomenon, positive and significant correlation between markets in different regions also exists; however, it is weaker than the correlation between markets in the same region, implying intraregional factors that influence the pricing of maize. These are factors related to regional and local maize supply and demand, the availability of both formal and informal maize markets, and differences in road networks and accessibility that affect local producers' ability to access more lucrative markets. In addition, transportation costs associated with moving maize grain from rural production areas to urban and peri-urban markets further influences maize prices in local markets that are in urban and peri-urban centers, with prices in such markets being higher. These findings therefore support the idea of regional "central" markets in the country, with the large urban markets of Mzuzu, Lilongwe, Limbe, and Blantyre being the main regional "central" hubs that drive regional local market prices.

The correlation coefficient measure between the SAFEX white maize price and the ADMARC maize price is 0.32 . This indicates a weak positive linear relationship and is acceptable via a shaky linear rule.

\section{Maize Price Volatility and Seasonality}

Maize prices in Malawi are far more volatile than other prices in the region. Figure 3.1 shows the monthly movements during the period January 2004 to October 2008 for some selected local maize markets in Malawi in comparison with four regional markets - the South African SAFEX market, Kenya, Zambia, 
and Mozambique — and the international maize markets, represented by the Chicago white maize price. Malawi maize markets were more volatile than either regional or international maize markets. It is also clear from Figure 3.1 that there is weak co-movement between domestic maize prices and the South African (SAFEX) white maize price.

Figure 3.1-Maize price co-movements in selected markets

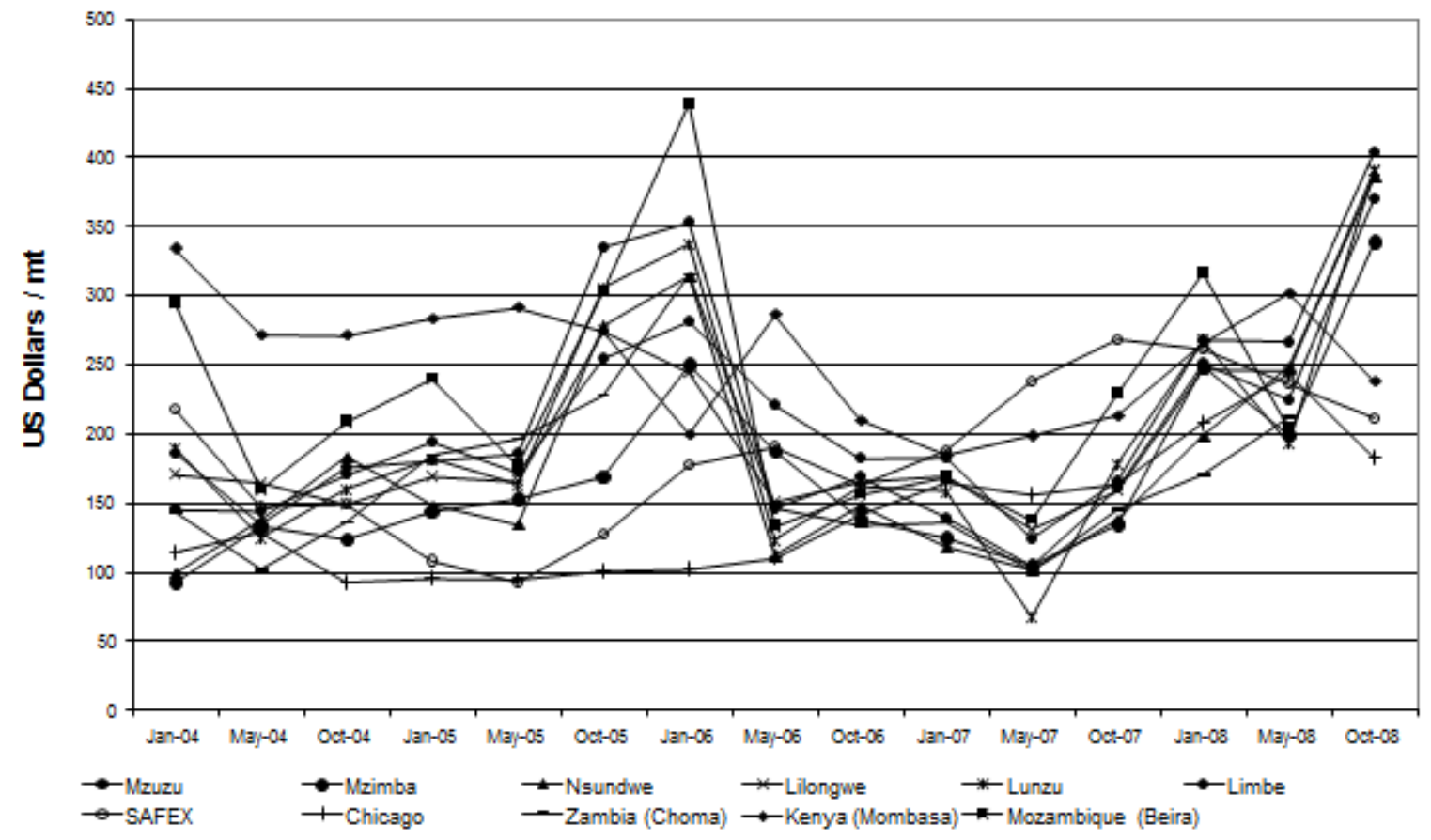

Source: Authors' compilation based on data from the Ministry of Agriculture and Food Security.

The ADMARC maize price tends to either rise or fall with the SAFEX white maize price. Correlation coefficient analysis shows that the ADMARC maize price is weakly correlated with the SAFEX maize price, indicating that other factors also influence maize pricing at the national level. These include, but are not limited to, government policies that directly affect maize pricing and trade, such as price bands; welfare considerations for low-income urban consumers; and considerations for resourcepoor maize producers (FAO 2009).

Another key issue that is clear from Figure 3.1 is that maize price volatility in Malawi is influenced by seasonal variations in maize grain stocks. First, in January of every year since 2004, with the exception of 2006, it can be seen that maize prices in all the six local markets are generally high. This can be attributed to food shortages often experienced by the majority of poor smallholder farmers during the month of January, as their maize grain from the previous season gets depleted while the current crop is still in the field. This period, dubbed the "hunger period," is characterized by food shortages that lead to high local-market maize prices. Surplus maize producers tend to keep their maize until this period in order to take advantage of the higher prices prevailing in local markets. The hunger period is further characterized by surplus maize producers' milling maize and packaging it into small packets, sufficient for one or two meals, which cost relatively more than either maize grain or milled maize at other times of the year. It is mainly rural smallholder farmers who are not food self-sufficient who depend on such milled maize. 
Figure 3.1 further shows that maize prices in the six local markets included tend to be lower during the month of May. This can be attributed to the availability of maize during the period of the main harvest. This is when the majority of poor smallholder farmers sell their maize in order to meet short-term cash needs (Jayne et al. 2010). They are then unable to take advantage of the higher maize prices that prevail during other times in the year when maize grain is scarce.

Another important contributor to maize price volatility in Malawi is unfavorable climatic conditions. An analysis of the historical ADMARC and local market price data shows that the movement of maize prices in the country is associated with erratic weather conditions, with price spikes observed in the 2001/02 and 2005/06 cropping seasons, following droughts that lowered maize production in those seasons. Furthermore, analysis of monthly maize price changes showed that in 2005 , monthly maize grain prices in all six markets included in Figure 3.1 increased greatly, with price increases of 32.2 percent, 52 percent, 39.4 percent, 46.4 percent, and 44.5 percent being observed between May and October of 2005 for the Mzuzu, Nsundwe, Lilongwe, Lunzu, and Limbe markets, respectively. These price spikes can be attributed to the drought that affected agricultural production in the 2004/05 cropping season. The price hike for the 2008/09 season can be attributed to very high official government maize production estimates for the 2007/08 cropping season, which led to the government's exporting maize to other countries in the region. This policy decision caused maize scarcity in Malawi and hence the higher maize prices (Jayne et al. 2010) in the 2008/09 season.

In addition, the markets in the central region (Lilongwe and Nsundwe) and in the southern region (Limbe and Lunzu) exhibited monthly increases in maize prices that were greater than 40 percent at the beginning of the 2005/06 agricultural season. Northern-region markets were, however, less volatile because the majority of smallholder farmers in the northern region are food self-sufficient, having more diversified food baskets that include other staple food crops such as rice and cassava. This situation is in contrast to other parts of the country, especially the southern region, where the majority of households are unable to meet their subsistence food requirements and hence depend largely on the market. Additionally, the southern region is densely populated, with households cultivating much smaller pieces of farmland (Malawi, NSO 2008), and some parts are highly prone to annual droughts and flooding (IFPRI 2009). As a result of these differences, the food security situation in the northern part of the country is often more favorable than in the southern region (FEWS NET 2010).

\section{Parity Price Analysis}

To further understand the Malawi maize market and to assess the incentives for maize production in the country, we carried out an import and export parity price analysis, with the South African white maize price being taken as the world price, or reference price, of maize for Malawi. The import parity price for maize in Lilongwe was calculated as the price of white maize in South Africa (Gauteng) plus transport costs, insurance, and tariffs. Figure 3.2 presents a comparison of the wholesale ADMARC maize price, the import parity price, the export parity price, and the volume of maize imports for a 20 -year period (1988/89 to 2008/09). Between 1988/89 and 2008/09, ADMARC maize prices more often either were above or approximated import parity price. Very high differences between the ADMARC wholesale price and the import parity price were observed in the 1992/93, 1997/98, 2001/02, and 2007/08 agricultural seasons, with the first three of these being years in which the country was hit by droughts. The higher price for the 2007/08 agricultural season cannot, however, can be explained by climatic factors, as government maize production data indicate that this was a good harvest year (Jayne et al. 2010). 
Figure 3.2 - Import and export parity price analysis

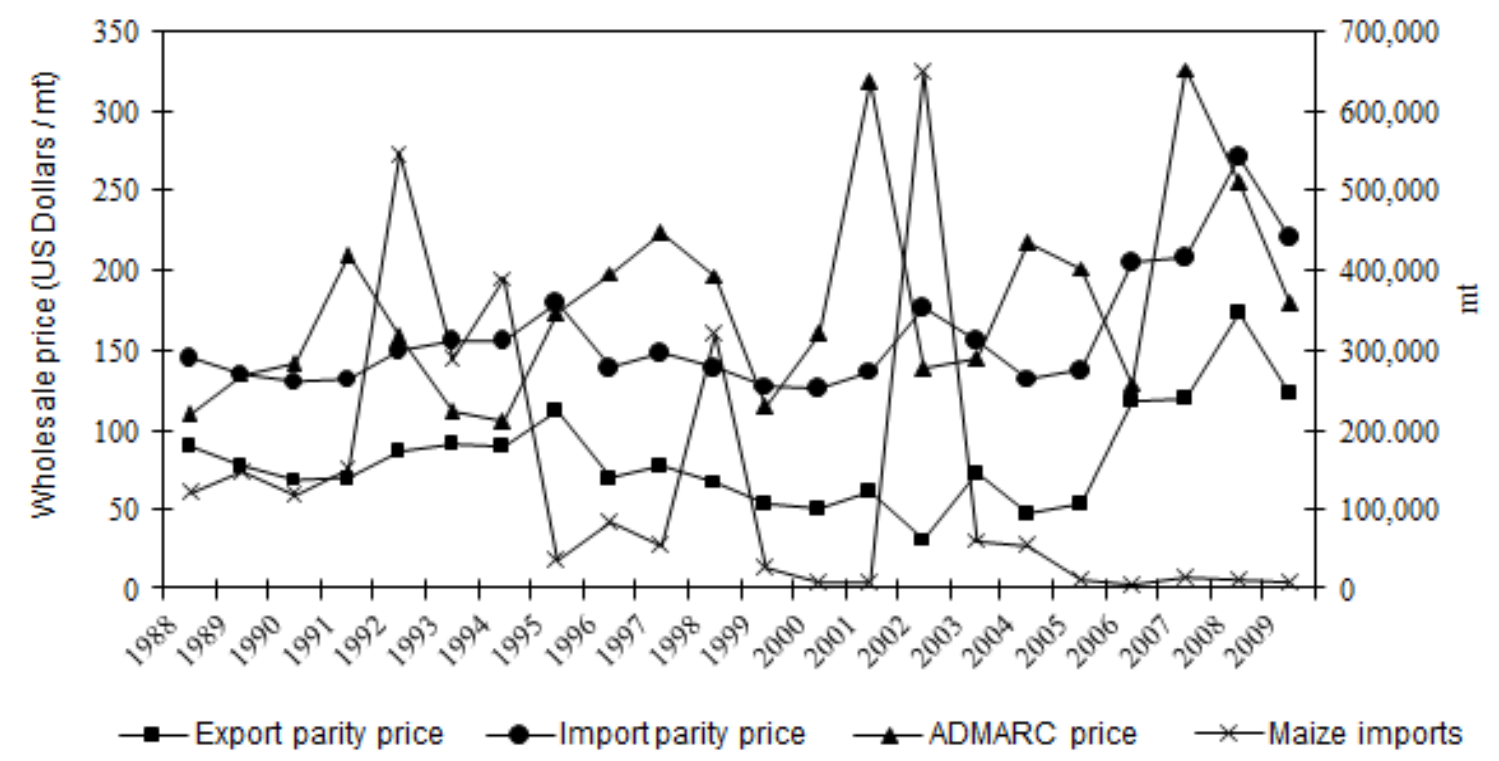

Source: Authors' compilation based on data from the Ministry of Agriculture and Food Security.

Further observation shows that, apart from the years in which the country was hit by drought, Malawi maize imports were generally nonresponsive to changing domestic prices. In theory, when wholesale domestic prices are higher than the import parity price, there is an incentive for traders to import goods into a country, as the imported good is cheaper than a locally produced good (FEWS NET 2008). From the observation above, it can be seen that despite the ADMARC price's being above or approximating import parity price, imports were not responsive. This is expected, though, since the government is the sole importer of maize. Only in the 1992/93 and 2002/03 cropping seasons were high maize prices positively correlated with maize imports. These were both years of extreme droughts, in which Malawi experienced severe food shortages. In these years there was also a lag between high maize prices and large maize imports, which shows the delays in response by the government. For the 2007/08 season, it can also be seen that the domestic wholesale (ADMARC) price for maize was much higher than the import parity price (as high as price differentials observed for both the 1992/93 and 2002/03 cropping seasons). However, in this season, maize imports remained low and nonresponsive. As stated earlier, this effect is attributed to the very high official government maize production estimates for the 2007/08 cropping season, which led to the government's exporting maize to other countries in the region.

Several issues arise from these observations. First, government policy and the government's perception of the domestic food security situation determine imports to a large extent. This is clearly evidenced by the government's importing large volumes of maize in the 1992/93 and 2002/03 cropping seasons, as opposed to the 2007/08 season. The government viewed the first two of these seasons as years of maize scarcity, while the latter, although exhibiting equally high maize prices, was not deemed an emergency. As a result of this discrepancy, maize imports in Malawi are nonresponsive to price changes, and it is clear that the government regulates maize trade and pricing in the country. Further, these observations imply that the Malawi maize market is not well integrated with regional maize markets. Hence, with the exception of years of very low food production, domestic maize prices in Malawi are unlikely to be affected by regional maize price changes. 
These findings concur with the statistical analysis carried out earlier, which showed no evidence of co-movement between local maize markets in Malawi and regional markets. The ADMARC price, however, exhibited a weak linear relationship with the SAFEX maize price. Hence, it is plausible to postulate that the world price of maize (as represented by SAFEX) has a weak but inconsistent influence on the ADMARC maize price. This is especially the case in years of droughts and in years of food shortages. Since the majority of maize imported into Malawi is from South Africa (Dana, Gilbert, and Shim 2006), in years of droughts and food shortages (1992/93, 1998/99, and 2002/03), the SAFEX white maize price had a stabilizing effect on the domestic maize price, because as imports reach the country, they reduce the gap between supply and demand and hence lead to a lowering of the domestic price.

In summary, local market maize prices are strongly influenced by the ADMARC maize price. However, geographical dynamics also have an influence on local market price. The ADMARC price is influenced by many factors, including domestic supply of and demand for maize; regional maize prices, particularly the South African white maize price; and climatic variability. Government price policies, however, are the greatest factor influencing ADMARC maize prices, with the country following a panterritorial discretionary regime in setting the national maize price. 


\section{MODEL SPECIFICATION}

This section draws upon the understanding in Section 3 of maize prices and the interlinkages between different market levels to build a partial equilibrium model of the maize market in Malawi. The model is a multiequation partial equilibrium model that is recursive in nature. Estimation of the single equations is based on economic theory as well as understanding of the economic and production dynamics of the maize subsector in Malawi. The model is presented below:

\section{Domestic Maize Supply Block}

Production

$$
Q P_{t}=A M_{t} \times Y M_{t}
$$

Area

$$
\log A M_{t}=a_{0}+a_{1} \log A M_{t-1}+a_{2} \log N P M_{t-1}+a_{3} D A G_{1}
$$

Yield

$$
\log Y M_{t}=a_{0}+a_{1} \log R n_{t}-a_{2} \log P F_{t}-a_{3} D A G_{2}+a_{4} S 06
$$

Beginning stock

$$
B S_{t}=E S_{t-1}
$$

\section{Domestic Maize Demand Block}

Consumption

$$
Q C_{t}=P C C_{t} \times P P_{t}
$$

Per capita consumption

$$
\log P C C_{t}=a_{0}-\log N P M_{t}+a_{2} \log p G D P_{t}-a_{3} T N_{t}+a_{4} D R-a_{5} D X P
$$

Ending stock

$$
E S_{t}=a_{0}+a_{1} B S_{t}+a_{2} Q P_{t}-a_{3} N P M_{t}
$$

\section{Price Block}

ADMARC maize price

$$
\log N P M_{t}=b_{0}+b_{1} \log I P P_{t}-b_{2} \log \left(Q P_{t} / Q C_{t}\right)+b_{4} D I-b_{5} D L I B
$$

\section{Model Closure}

Imports

$$
\log I M_{t}=a_{0}-a_{1} \operatorname{logNX} P_{t}-a_{2} S 06+a_{3} D p v t+a_{4} D N F
$$

Net exports

$$
N X P_{t}=Q P_{t}-Q C_{t}+B S_{t}-E S_{t}
$$

Exports

$$
X P_{t}=N X P_{t}+I M_{t}
$$

\section{Variables}

$\begin{array}{ll}Q P_{t} & \text { Domestic maize production (thousand } \mathrm{mt} \text { ) } \\ A M_{t} & \text { Area planted (ha) } \\ Y M_{t} & \text { Yield (mt/ha) } \\ N P M_{t} & \text { National (ADMARC) price of maize (US dollars / mt) } \\ R n_{t} & \text { Total annual rainfall (mm) } \\ P F_{t} & \text { Local price of fertilizer (US dollars / mt) } \\ B S_{t} & \text { Beginning stock (thousand } \mathrm{mt} \text { ) } \\ E S_{t} & \text { Ending stock (thousand } \mathrm{mt} \text { ) }\end{array}$




$\begin{array}{ll}Q C_{t} & \text { Domestic maize consumption (thousand } \mathrm{mt} \text { ) } \\ P C C_{t} & \text { Per capita consumption (mt/capita) } \\ p G D P_{t} & \text { Per capita gross domestic product } \\ P P_{t} & \text { Population (millions) } \\ I P P_{t} & \text { Import parity price } \\ I M_{t} & \text { Maize imports (thousand } \mathrm{mt} \text { ) } \\ N X P_{t} & \text { Net exports (thousand } \mathrm{mt} \text { ) } \\ X P_{t} & \text { Maize exports (thousand } \mathrm{mt} \text { ) }\end{array}$

\section{Dummy Variables}

$D A G_{1} \quad$ Public recruitment: extension service retraining $(0 / 1)$

$D A G_{2} \quad$ Maize irrigation program changes $(0 / 1)$

$D R \quad$ Emergency food relief years $(0 / 1)$

$D X P \quad$ Policy allowing large volumes of exports $(0 / 1)$

DNF Policy allowing large volumes of imports $(0 / 1)$

DI Government price policy interventions $(0 / 1)$

DLIB Reforms in maize marketing $(0 / 1)$

Dpvt Greater private-sector involvement in maize trade

S06 Shift variable: shift to full input fertilizer subsidy program in 2005/06

$T_{t} \quad$ Trend variable

\section{Other}

$t \quad$ Time index

a Elasticities in the supply, demand, and trade equations

$b$ 's Price elasticity

The following are some key features of the national maize model for Malawi:

1. Farmers in the maize-based farming system play the dual role of producer and consumer; hence, they are affected by both demand- and supply-side dynamics.

2. The majority of farmers within the maize-based farming system in the country do not substitute maize with any other crops. In the absence of substitute goods, the homogeneity condition will not strictly hold, and as such, the standard errors of the estimated models may be biased upward, thus reducing the magnitude of significance of the estimated coefficients (Fuglie, Suherman, and Adiyoga 2002). However, this is a reasonable trade-off so long as the estimated equations reasonably reflect the real maize-based farming system in Malawi. It is therefore expected that all estimated demand- and supply-related equations will exhibit price inelasticity, as this is a sign that the commodity under analysis has no close substitutes (Tewari and Singh 1996).

3. In the absence of substitutes, the symmetry matrices cannot be estimated, since there are no cross-price elasticities.

Due to the nature of the maize-based farming system in Malawi as well as other institutional factors, the single-equation estimation does not adhere only or strictly to economic theory, but includes aspects based on empirical evidence and institutional factors that affect the maize-based farming system, including the following: 


\section{Domestic Supply Block}

1. In economic theory, area harvested is modeled as a partial adjustment function with the current maize prices and the prices of other crops (Agcaoili and Rosegrant 1995). In equation (2), the lagged ADMARC maize prices have been used, as opposed to current maize prices. This is because Malawi does not have a futures market, but ADMARC prices are announced at the end of the cropping season. Farm production decisions are therefore based on the prices from past seasons.

2. For maize production, the price of substitutes has not been included in the equation, as the majority of smallholder farmers within the maize-based farming system are also consumers of their own crop and hence do not produce solely for the market. Therefore, they do not substitute maize for other crops, regardless of the price.

3. Typically, yield functions are estimated as a function of past yields in combination with other variables (Agcaoili and Rosegrant 1995). Lagged yields, however, are not included in this study, as empirical evidence demonstrates that crop yield variability in Malawi is mainly due to climatic factors, especially erratic rainfall, which results in recurrent droughts in some years and floods in others (Kanyama-Phiri 2008).

\section{Domestic Demand Block}

1. Domestic maize demand in Malawi is mainly composed of domestic human consumption, with some maize going toward seed and feed or industrial use and ending stock. Data for seed, feed, and industrial use in Malawi are unreliable and difficult to obtain. Therefore, total domestic maize demand is taken as a function of domestic consumption and ending stock, with seed, feed, and industrial use being incorporated as exogenous variables in the mathematical calculation of aggregate domestic demand.

2. The modeling of ending stock follows Gallagher's (1981) approach.

\section{Maize Price Block}

1. The determination of maize prices in Malawi is a complex matter confounded by government intervention.

2. The estimation of the national producer price of maize (the ADMARC price) thus includes dummy variables that capture the liberalization of ADMARC (DLIB) and direct government price policies $(D I)$. Different dummy variables have been included in the price equation to capture the effects of government policy instruments on the pricing of maize in the country. Appendix B provides a historical background of ADMARC reforms and their effects on price.

\section{Model Closure (Trade Block)}

1. Maize exports and imports are relatively small in comparison with domestic maize production, implying that maize prices are essentially determined by the dynamics of domestic demand and supply, apart from policies. Since the late 1980s, maize prices in Malawi have approximated import parity prices. In such cases, it is expected that the country would be a net exporter of maize, that domestic prices would largely be determined by world prices, and that this would be reflected in a high price transmission rate (Meyer et al. 2006). However, this has not been the case in Malawi due to government intervention. 
2. Given this situation, the Malawi maize market is taken as being under an import parity regime, with the ADMARC maize prices determined by a behavioral price linkage equation (equation [8]). Price linkage equations define the extent of price transmission from world markets to domestic markets (Helmar, Devadoss, and Meyers 1991; Meyers, Devadoss, and Helmar 1991). As such, they are considered appropriate in markets in which domestic prices are determined by world prices (Pearse, SriRamaratnam, and Daké 1994; Meyer et al. 2006). The Malawi maize market is not well integrated with world markets because its price transmission is insulated by government intervention. Nevertheless, the use of a price linkage equation is still relevant because trade still takes place, even though full price transmission is not allowed, trade flows being constrained by the government (Helmar, Devadoss, and Meyers 1991; Meyers, Devadoss, and Helmar 1991). The price linkage equation that has been specified for this model therefore includes not only import parity prices but also other domestic factors, including direct government price intervention, maize market reforms, and domestic demand-and-supply dynamics, which play an important role in determining ADMARC maize prices.

3. Therefore, the Malawi maize market is under an import parity regime, but one in which the level of correlation between the domestic price and the world price is less than 1 due to government control. This has been reflected in the specification of the price linkage equation for domestic maize prices. Under an import parity regime, net exports are used as a closing identity for the model (Meyer et al. 2006).

4. The model is solved using the Gauss-Seidel iterative algorithm, which involves a stepwise iterative process to estimate a solution (Ferris 1998).

Equations (1) through (11) represent the national-level maize market. The national maize market is linked to local market economies using a price linkage equation of the ADMARC maize price (equation [8]). This linkage is based on an understanding of the relationship between prices in the national market and the local market (Section 3). The local-economy model, with the price linkage through the local maize price, is presented below:

\section{Local Maize Economy}

$$
\begin{array}{lr}
\text { Local consumption } & \log L Q C_{t}=a_{0}+a_{1} \log L Q P_{t}-a_{2} \log L P M_{t-1}-a_{i} D A_{i} \\
\text { Local production } & \log Q L P_{t}=a_{0}+a_{1} L R n_{t}+a_{2} L P M_{t-1}-a_{i} D K_{i} \\
\text { Local maize price } & \log L P M_{t}=b_{0}+b_{1} \log N P M_{t}-b_{2} \log L Q C_{t}+b_{3} D 02-b_{i} D K_{i}
\end{array}
$$

\section{Variables}

$L Q C_{t} \quad$ Aggregate local maize consumption for an extension planning area (thousand $\mathrm{mt}$ )

$L Q P_{t} \quad$ Aggregate local maize production for an extension planning area (thousand $\mathrm{mt}$ )

$L P M_{t} \quad$ Local price of maize in market nearest to extension planning area (US dollars / $\mathrm{mt}$ )

$Q L P_{t} \quad$ Aggregate local maize production (thousand $\mathrm{mt}$ )

$L R n_{t} \quad$ Total local annual rainfall $(\mathrm{mm})$

\section{Dummy Variables}

$D K_{2} \quad$ Years with concurrent climatic occurrences in local area

$D A \quad$ Factors that affect accessibility to local area, such as road conditions, lack of a bridge

D02 Drought (2001/02 season) 
$D K_{t} \quad$ Agricultural extension programs that negatively

affect production data, such as years with erroneous crop production estimates

Some key features of the local economy block:

5. The local rural maize market economy is linked to the national maize market via a price linkage equation with the ADMARC maize price (equation [14]). The method of linking the local market via the ADMARC price linkage equation can be replicated for all markets in Malawi with the empirical estimation capturing local area-specific production, consumption, price, and other factors.

6. Local maize consumption (equation [12]) is modeled as a function of local maize production (equation [13]) and other variables (local price of maize and dummy variables that affect accessibility to an area). The inclusion of local production in the local consumption equation creates a feedback loop because local population dynamics and changes that occur in local maize production filter through to local maize consumption, affecting maize prices in local markets and thus creating a recursive system at the local economy level. Local maize consumption in combination with the ADMARC maize price determines prices in local maize markets. Price changes occurring in local maize markets affect farm/household-level maize pricing, and this in turn affects household income portfolios. Through this linkage, changes occurring within national maize markets and those occurring within local economies are felt at the household level and are manifested as changes in household income. This feedback effect, henceforth referred to as the local area consumption loop, creates a recursive system of the local maize market.

7. The local area consumption loop allows the model to also be used to assess the impact of macroeconomic and agricultural-sector policy changes on rural household incomes that traditionally are considered to have little or no backward and forward linkages.

8. The equation for local maize production is estimated as a function of rainfall received in the local area, the lagged maize price in the local market, and a dummy variable capturing the years in which the local area experienced concurrent natural disasters (for example, a combination of floods, long dry spells, and diseases and pests in one cropping season).

9. The yield and the acreage of maize planted/harvested are not included in the equation for local maize production because data at the level of the extension planning area for these variables is highly inconsistent and discontinuous.

10. Because rural household income data at extension planning area level are often not available, a household income variable has not been included in the local consumption equation, even though household income is known to influence staple food consumption patterns in semi subsistence communities such as those that are commonly found in Malawi. The maize production variable, however, does reflect household income, since maize accounts for the largest share of household income in rural household income estimations, especially for households that do not have lucrative commercial enterprises or large ownership of livestock.

If household data are available, a household income variable can be included in the estimation of local consumption, and equation (12) can be rewritten as follows:

Local consumption with household income:

$$
\log L Q C_{t}=a_{0}+a_{1} \sum_{i=1}^{n} y_{m}^{t}-a_{2} \log L P M_{t-1}-a_{3} D A C C,
$$

where $\sum_{i=1}^{n} y_{m}^{t}$ is aggregate rural household income for all households in an extension planning area. 
In rural Malawi, household income is not synonymous with cash wage income but is rather a computed value that consists of wage income, income earned from self-employment (such as business and sales of own crops and livestock), and the imputed value of crops and livestock kept for home consumption. In such cases, household income estimates come from a system of equations that consists of the earnings equation for household members who are of working age and who therefore contribute economically to the household; self-employment equations that estimate the potential income that can be earned from self-employment; and occupational choice equations that describe the allocation of time by working-age individuals within the household between wage employment, self-employment, and nonfarm/nonlabor time. The methodology in equation (15) for estimating rural household income $\left(y_{m}^{t}\right)$ has followed this approach, adapted from the work of Bourguignon, Fournier, and Gurgan (2001); Alantas and Bourguignon (2004); and Robilliard, Bourguignon, and Robinson (2008).

The derivation of rural household income is as follows: Let $y_{i t}$ denote household income for household $i$ at time $t$. It is assumed that income $y_{i t}$ depends through a function $y()$ and there are four main arguments governing the relationship:

1. The observed socioeconomic characteristics of different household members $(x)$

2. The unobserved socioeconomic characteristics of different household members, $(\varepsilon)$

3. The set of remuneration prices that these characteristics are given in the labor market $(\beta)$

4. A set of parameters that define the participation and occupational choices of different household members $(\lambda)$

Given this, household income can be expressed as follows:

$$
y_{i t}=Y\left(x_{i t}, \varepsilon_{i t}, \beta_{t}, \lambda_{t}\right)
$$

The following four equations provide a decomposition of equation (16):

$$
\begin{gathered}
\log w_{m i}^{t}=X_{m i}^{t} \beta^{t}+u_{m i}^{t} ; i=1, \ldots k_{m} \\
L_{m i}^{t}=\operatorname{Ind}\left[X_{m i}^{t} \lambda_{1 X}^{t}+Z_{m i}^{t} \lambda_{i Z}^{t}+v_{m i}^{t}\right] ; i=1, \ldots k_{m} \\
L_{m i}^{A t}=\operatorname{Ind}\left[X_{m i}^{t} \lambda_{2 X}^{t}+Z_{m i}^{t} \lambda_{2 Z}^{t}+v_{m i}^{A i}\right] ; i=1, \ldots k_{m} \\
L_{m i}^{N A t}=\operatorname{Ind}\left[X_{m i}^{t} \lambda_{3 X}^{t+}+Z_{m i}^{t} \lambda_{3 Z}^{t}+v_{m i}^{N A t}\right] ; i=1, \ldots k_{m}
\end{gathered}
$$

Equation (17) is a typical Mincer earnings equation, and it gives the log of the wage earnings for individual household members $(i)$ for a specific household $(m)$ expressed as a function of a set of personal characteristics $(X) .{ }^{1} u_{m i}^{t}$ is the residual term, and it describes the effects of unobserved determinants of wage earnings. Earnings are modeled as a function of personal characteristics of only those household members who are able to earn an income. This enables capturing of the heterogeneity of earnings within

\footnotetext{
${ }^{1}$ The Mincer earnings equation is commonly a log-linear function because it is an empirical operationalization of the human capital model. The human capital model stipulates that individuals invest in human capital up to the point where investment costs just equal the present value of schooling gains. This stipulation implies that during the postschool phase, levels of investment in human capital decline monotonically until they reach zero at retirement. Since potential earnings are proportional to human capital stock, it is implied that potential earnings also increase at a decreasing rate over a life cycle. The log-liner earnings wage function is therefore the empirical application of the linear declining postschool investment theory. See Lemieux (2006) and Polackek (2007) for details.
} 
different income groups, which may arise due to differences in socioeconomic characteristics (Ahmed and Donoghue 2010).

Equations (18) through (20) represent the occupational choices available to each household member who contributes toward household income. Salaried employment from both on- and off-farm income is captured by equation (18) as $\left(L_{m i}^{t}\right)$. This represents the labor supplied by a household member $i$ as a wage earner outside the household. The real and imputed income from all upland crops except maize, livestock income, income from wetlands, and the real and imputed value of maize fall into equation (19) as $\left(L_{m i}^{A t}\right)$, representing all labor supplied by a household member $i$ on the farm that the household owns and cultivates. Finally, non-agro-based commercial enterprises and agro-based commercial enterprises of the household fall under equation (20) as $\left(L_{m i}^{N A t}\right)$, which represents the labor supplied by a household member $i$ on the family's nonfarm/nonlabor income-generating activities. The $v_{m i}$ 's are the residual terms, and they represent the unobserved factors that determine household members' occupational choices.

The coefficient estimates for the occupational choices of different household members $(\lambda)$ are represented by the $X_{m i}$ 's and $Z_{m i}$ 's, and as can be observed from the three occupational choice equations, these are common for all individuals within a household. However, these may differ across demographic groups - that is, between male and female household members or between older and younger household members. The vector $Z$ captures household characteristics that include mainly productive assets such as land, while $X$ is a vector of the standard human capital variables, such as years of schooling and access to training. The labor supply parameter $\lambda$ has three subsets $\left(\lambda_{1}\right.$ for wage labor, $\lambda_{2}$ for self-employment, and $\lambda_{3}$ for nonfarm/nonlabor income) that differ depending on the household member under consideration.

Occupational choices are all modeled as a discrete logit model in which the household member has only two choices, either to supply labor or not to supply labor. Labor is modeled as a discrete variable because the actual number of working hours per household member in each occupation is not captured (Alantas and Bourguignon 2004; Robilliard, Bourguignon, and Robinson 2008). This modeling technique is represented in the three occupational choice models by the notation Ind.

The aggregate household income is then obtained using an accounting identity that sums the wage income, earnings from self-employment (value of own production), and nonlabor income as well as an exogenous variable for incomes earned from remittances and other cash transfers. Aggregate rural household income can therefore be presented as follows:

$$
y_{m}^{t}=\sum_{i=1}^{k_{m}} L_{m i}^{t} w_{m i}^{t}+\prod_{A}^{t}\left\lceil Z_{m}^{T t}, \sum_{j=1}^{k_{m}} L_{m i}^{A t}, s_{A}^{t}, \beta_{A}^{t}\right\rceil+\prod_{N A}^{t}\left\lceil Z_{m}^{T t}, \sum_{j=1}^{k_{m}} L_{m i}^{N A t}, s_{N A}^{t}, \beta_{N A}^{t}\right\rceil+y_{0 m}^{t},
$$

where

$$
\begin{array}{ll}
\prod_{A}^{t} & =\text { profit function for self-employment income (value of own production); } \\
\prod_{N A}^{t} & =\text { profit function for nonfarm/nonlabor income; } \\
y_{0 m}^{t} & =\text { exogenous variable representing transfers of income (remittances); and } \\
s_{A}^{t} \text { and } s_{N A}^{t} & =\text { residuals of the profit functions, which can represent either the unobserved } \\
& \text { factors determining profits or measurement errors. }
\end{array}
$$

Equation (21) shows that aggregate household income is a nonlinear function of wage income, profits generated from self-employment, profits generated from nonfarm/nonlabor income, various occupational choices for different household members, an exogenous parameter from transfers $y_{0 m}^{t}$, and the observed household characteristics of different household members who are of income-earning age.

The summation of all aggregate incomes for all households in an extension planning area $\left(\sum_{i=1}^{n} y_{m}^{t}\right)$ or any other local area is the one included in the estimation of the local consumption equation (equation [14]).

Figure 4.1 presents a diagrammatic representation of the national maize market with linkages to the local market economy and rural household incomes. 
Figure 4.1—Structure of the Malawi maize market

\section{Local economy}

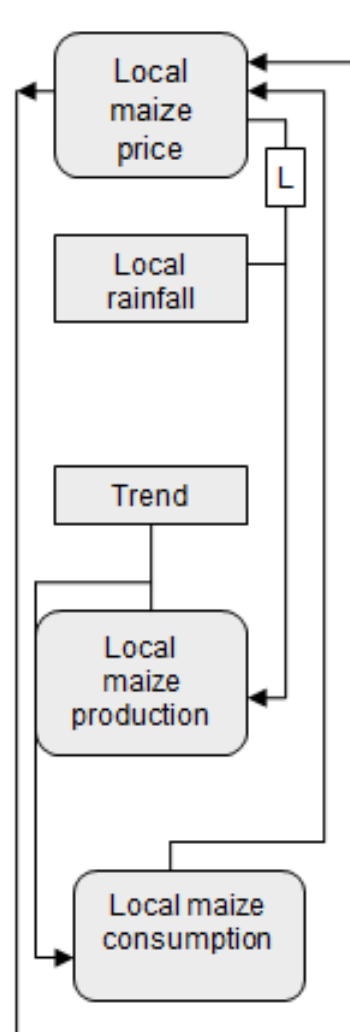

: Author design.

Note: GDP = gross domestic

product.
National (macro-level) maize market

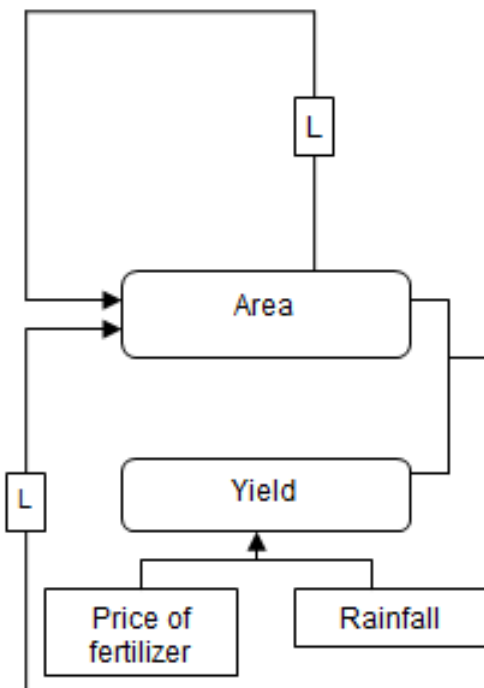

Key variable

ㄴ. Lag

fertilize
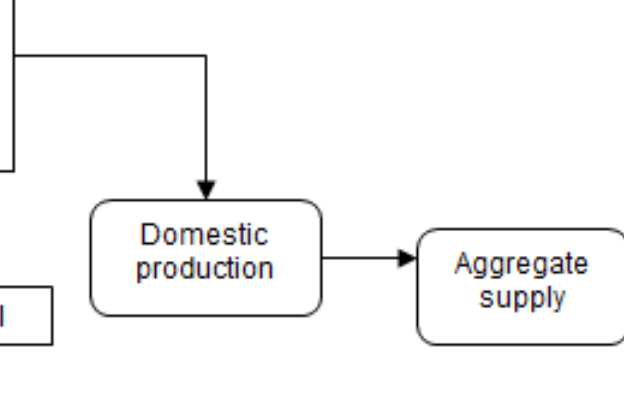

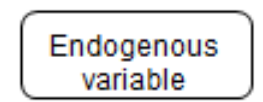
variable

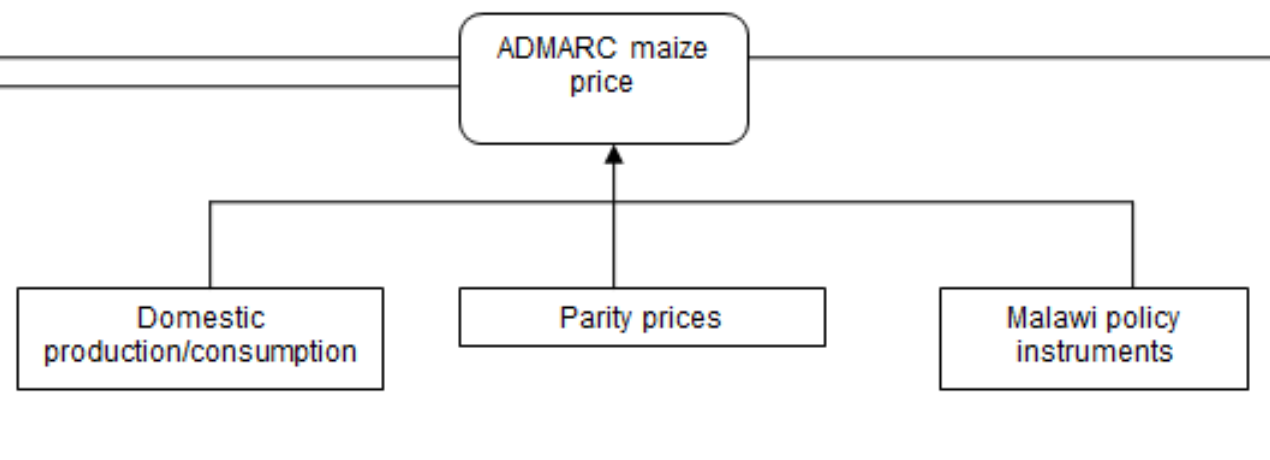

production/consumption
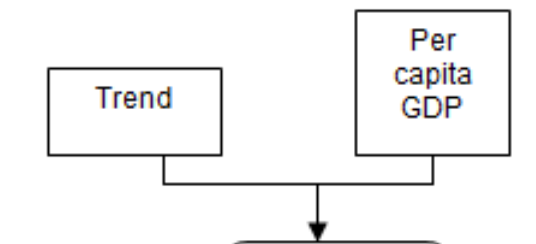

$\checkmark$

Per capita maize
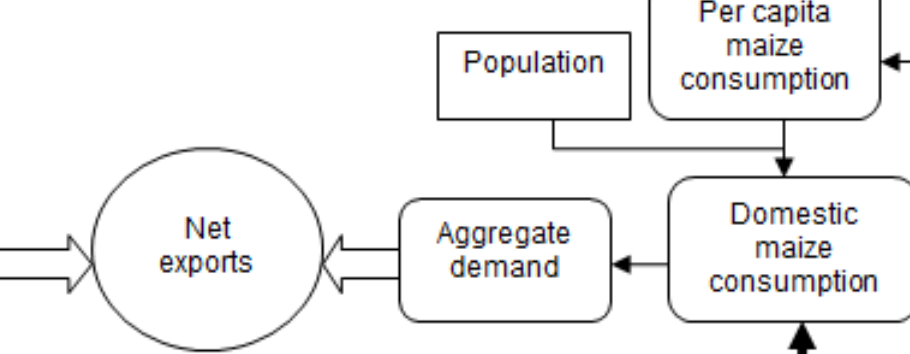
demand

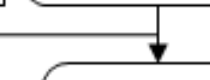

Domestic consumption

Household income (with maize income)

Source: Authors' creation. 


\section{Single Equation Validation}

The ability of a simulation model to correctly predict the key turning points in actual data is an important criterion for model assessment (Pindyck and Rubinfeld 1991). Therefore the single equations were estimated separately using historical time series data, and three tests of robustness were carried out in order to validate and check the ability of the model to effectively simulate the historical path of the real data.

First each single equation was validated using the R-square statistic and the root mean square error (RMSE) to test for the relative fit and the absolute fit to the actual data, respectively. Since the partial equilibrium model has been developed mainly for simulation, the RMSE is the key criterion for accepting a fitted equation because the RMSE measures the deviation of the estimated variable from its true path (Ferris 1998). The RMSE also helps to overcome the conflicting interests of model interpretability and goodness of fit, since it takes into account the number of parameters that have been included in a model and, as such, it does not improve as more parameters are added to the estimated model (Browne and Cudeck 1992). As a rule of thumb, a model is accepted as a good fit of actual data if the RMSE does not deviate much from zero (Browne and Cudeck 1992). The F-statistic was used to test the overall goodness of fit of the estimated equations in order to test for significance of the estimated equations and ability of all the independent variables to effectively predict the dependent variable.

The fitted single equations with the various robustness tests are presented in Table 4.1.

Table 4.1-Single equation validation: Fitted equations with robustness tests

\begin{tabular}{|c|c|c|c|}
\hline \multicolumn{4}{|l|}{ Domestic supply block } \\
\hline 1. Domestic maize production (identify) & \multicolumn{3}{|c|}{ Area * Yield } \\
\hline 2. Area of maize planted & Parameter & $t$-value & Elasticity \\
\hline Intercept & 1802.2 & 1.550 & \\
\hline $\mathrm{NPM}_{\mathrm{t}-1}$ & 0.006 & 0.075 & 0.013 \\
\hline $\mathrm{AM}_{\mathrm{t}-1}$ & 0.653 & $2.978^{\star \star}$ & 0.021 \\
\hline $\mathrm{DAG}_{1}$ & 104.59 & $0.506^{\star * *}$ & \\
\hline$\overline{R^{2}}=0.678$ & RMSE $=0.043$ & \multicolumn{2}{|c|}{$F$-value $=7.901^{* *}$} \\
\hline 3. Yield of maize & Parameter & $t$-value & Elasticity \\
\hline Intercept & 0.010 & 1.194 & \\
\hline $\mathrm{Rn}_{\mathrm{t}}$ & 0.002 & $5.749^{\star \star *}$ & 1.80 \\
\hline $\mathrm{PF}_{\mathrm{t}}$ & -0.003 & $-1.759^{\star}$ & -0.52 \\
\hline S06 & 0.5 & $2.621^{*}$ & \\
\hline $\mathrm{DAG}_{2}$ & -0.05 & $-3.831^{* *}$ & \\
\hline$\overline{R^{2}}=0.789$ & RMSE $=0.013$ & \multicolumn{2}{|c|}{$F$-value $=20.67^{* * *}$} \\
\hline 4. Beginning stock (identity) & \multicolumn{3}{|c|}{ Lagged ending stocks } \\
\hline \multicolumn{4}{|l|}{ Domestic demand block } \\
\hline 5. Domestic consumption (identity) & & \multicolumn{2}{|c|}{ Per capita consumption * Population } \\
\hline 6. Per capita consumption & Parameter & $t$-value & Elasticity \\
\hline Intercept & 110.881 & 1.583 & \\
\hline $\mathrm{NPM}_{\mathrm{t}}$ & -0.201 & $-3.074^{\star \star}$ & -0.233 \\
\hline $\mathrm{TN}_{\mathrm{t}}$ & -0.015 & $-3.228^{* *}$ & -0.001 \\
\hline $\mathrm{pGDP}_{\mathrm{t}}$ & 0.395 & $3.487^{\star *}$ & 0.474 \\
\hline DR & 14.20 & $3.955^{\star \star}$ & \\
\hline DXP & -18.00 & $-2.961^{*}$ & \\
\hline$\overline{R^{2}}=0.897$ & $R M S E=0.028$ & \multicolumn{2}{|c|}{$F$-value $=35.874^{\star \star *}$} \\
\hline 7. Ending stocks & Parameter & $t$-value & Elasticity \\
\hline Intercept & 0.017 & $2.095^{*}$ & \\
\hline $\mathrm{BS}_{\mathrm{t}}$ & 0.41 & $2.760^{*}$ & 0.50 \\
\hline $\mathrm{QP}_{\mathrm{t}}$ & 0.001 & $3.683^{\star *}$ & 0.67 \\
\hline $\mathrm{NPM}_{\mathrm{t}}$ & -0.002 & -2.400 & -0.18 \\
\hline$\overline{R^{2}}=0.727$ & $R M S E=0.062$ & F-valuc & \\
\hline
\end{tabular}


Table 4.2-Continued

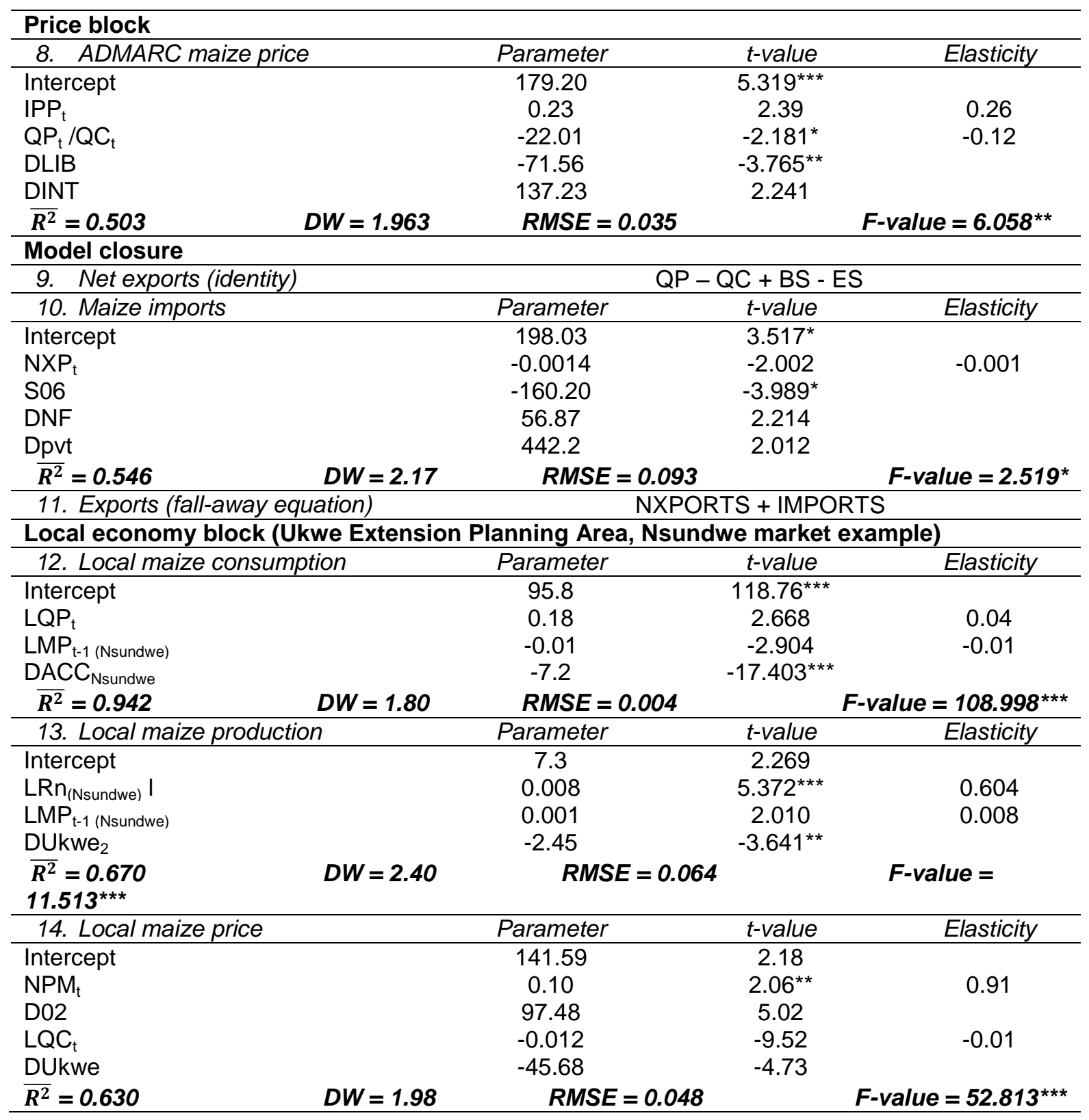

Source: Authors' calculations.

Notes: * Significant at $10 \%$ level, ** significant at 5\% level, *** significant at $1 \%$ level.

$\mathrm{LQP}_{\mathrm{t}}=$ maize production in Ukwe Extension Planning Area $(\mathrm{mt}) ; \mathrm{LMP}(\mathrm{Nsundwe})=$ price of maize in the Nsundwe market in Ukwe (US dollars $/ \mathrm{mt}) ; \mathrm{LRn}_{(\mathrm{Nsundwe})}=$ average annual rainfall in $\mathrm{Ukwe}(\mathrm{mm}) ; \mathrm{LQC}_{\mathrm{t}}=$ total estimated local maize consumption for Ukwe (thousand $\mathrm{mt}$ ); D02 = dummy variable capturing effects of the 2001/02 drought (0/1); DUkwe = dummy variable capturing the effects of overestimated crop estimates for Ukwe; DUkwe ${ }_{2}=$ dummy variable for years with concurrent natural disasters (floods, long dry spells, locusts) (0/1); $\mathrm{DACC}_{\mathrm{N} \text { sundwe }}=$ accessibility dummy variable: main bridge to Ukwe unusable (0/1).

From Table 4.1 it can be seen that, first, each of the fitted single equations has an adjusted Rsquare statistic that is greater than 50 percent, implying that at least 50 percent of the total variation in each of the endogenous variables is explained by the estimated equation. The fitted single equations for 
local maize consumption and per capita consumption have adjusted R-square statistics that explain about 90 percent of the total variation in the endogenous variables. Second, each of the fitted equations has an RMSE that is not far from zero, implying that the absolute fit of each of the fitted equations is not far from the actual data. Finally, each of the fitted single equations has an F-value that is statistically significant, with the equations for the yield of maize, per capita consumption, ending stock, local maize consumption, local maize production, and local maize prices having F-statistics that are highly statistically significant. This therefore implies that each estimated equation, as a whole, is able to effectively explain the variation of the endogenous variable being modeled.

It should be noted that the use of lagged variables in estimating the single equations can lead to first-order serial correlation. In such cases, the parameter estimates are inefficient; however, they remain unbiased, consistent, and asymptotically normal (Pindyck and Rubinfeld 1991). Based on this as well as that the serial correlation in this study is the result of inertia and economic phenomena (that is, lagged area of maize planted and lagged maize prices), we accept the serial correlation. Thus, the goodness-of-fit test statistics will be slightly inflated (Pindyck and Rubinfeld 1991); however, they remain valid as long as the data used are stationary (Wooldridge 2009). Stationarity of all the time-series data used in developing the Malawi maize model was established earlier, in Section 2, and therefore the goodness-offit measures for the $t$ model remain acceptable.

\section{Overall Model Performance}

The three robustness tests (adjusted R-square statistic, RMSE, and F-statistic) validate the single equations separately, but they do not provide a check for the partial equilibrium model as a whole. To test for overall model performance, the study employed different types of sensitivity analysis. First, small changes were made to the paths of three exogenous variables - rainfall, population, and gross domestic product (GDP) - in the model. From these changes, it was observed that there were very small changes in the historical simulation of the endogenous variables. Second, small changes were made to the coefficient estimates for the fitted single equations, and it was observed that the historical simulation of the model did not alter significantly as a result. Therefore, the Malawi maize model as a whole is an appropriate representation of the real maize subsector, since small changes in the paths of some selected exogenous variables and small changes in the parameter estimates of the endogenous variables do not radically alter the performance of the historical simulation, as is the case in the real world (Pindyck and Rubinfeld 1991).

In summary, a functioning partial equilibrium model of the Malawi maize market has been developed in the face of market imperfections arising from government price controls. 


\section{CONCLUSION AND MODEL LIMITATIONS}

This paper has presented the process of developing a multiequation partial equilibrium model of the Malawi maize market in the face of market imperfections. An establishment of the interrelationships between farm/household, local-economy, and national maize market prices, as well as economic theory and existing empirical evidence, has been able, through a local area consumption loop, to create a recursive system of the local maize market. The local maize market is linked through a price linkage equation with the national maize market, hence effectively capturing the process through which maize prices transmit from the macroeconomy to rural households.

Using the model that is developed, it is possible to simulate the impacts of policy changes on rural subsistence households that are involved in the production and marketing of maize. The process of developing the model provides great insight for understanding the formation of maize prices in Malawi and the interlinkages between different levels of markets within the country. The model thus developed can be used by the Malawi government to improve ADMARC's price-setting strategy. ADMARC can use the model to simulate how differing maize supply-and-demand and geographical dynamics will affect local, regional, and national maize pricing as well as household welfare. In so doing, ADMARC can shift from the current pan-territorial discretionary price-setting regime to one that differs across the country depending on regional production levels as well as welfare considerations. Such a system would facilitate maize trade so that maize flows from areas of high production to areas with recurrent shortages, where both ADMARC and private trader prices would be higher.

A key limitation of the model is that the linkage between national and local-economy markets with rural households is unidirectional (top-down) and therefore feedback effects from the household level to the local and macroeconomy levels are not captured. This is a weakness of the model because in reality, changes occurring at the household level have an impact on the national maize market. Future research should therefore focus on developing an aggregate household income variable that could be used to analyze the impact of changes in rural household incomes on the sector and the macroeconomy in general. Such a variable can be developed by the use of behavioral models to develop functional forms for the local economy, using either behavioral linkage techniques or a mixture of parametric techniques with microaccounting to create the macro-micro linkage. The parametric estimation of an aggregate household income variable and the behavioral linkages of the micro component to the macro component would change the existing Malawi maize model from a sequential model without upward feedback effects to a fully integrated model with feedback from the micro component (household level) to the macro component (national level). In addition, it is also recommended that future studies aim to assess the use of household expenditure as a means of linking rural smallholder farmers to the macroeconomy, thus quantifying linkages of rural households to agricultural input markets. 


\section{APPENDIX A: VARIOUS STATISTICAL TEST RESULTS}

Table A.1-Augmented Dickey-Fuller test results, maize-sector data

\begin{tabular}{lccc}
\hline Dataset & $\begin{array}{c}\text { Augmented Dickey- } \\
\text { Fuller statistic }\end{array}$ & $\begin{array}{c}\text { MacKinnon critical } \\
\text { value }\end{array}$ & Levels/differences \\
\hline Maize production & -3.843 & -3.000 & 1 st difference \\
Domestic maize consumption & -4.095 & -3.000 & 4 th difference \\
Ending stock & -4.436 & -3.000 & 1 st difference \\
Area of maize & -4.342 & -3.000 & 1 st difference \\
Yield of maize & -7.905 & -3.000 & 1 st difference \\
Population & -2.760 & -3.000 & 1 st difference \\
Exports & -3.320 & -3.000 & 1 st difference \\
Imports & -4.280 & -3.000 & 1 st difference \\
Exchange rate & -4.395 & -3.000 & 1 dt difference \\
Rainfall & -4.280 & -3.000 & Levels \\
ADMARC maize price & -4.176 & -3.750 & Levels \\
\hline Consumer price index: food & -5.728 & -3.000 & $2 n d$ difference \\
\hline
\end{tabular}

Source: Authors' calculations based on Ministry of Agriculture and Food Security data.

Table A.2-Augmented Dickey-Fuller test results, local market maize prices

\begin{tabular}{|c|c|c|}
\hline Maize market & $\begin{array}{c}\text { Augmented Dickey-Fuller } \\
\text { statistic }\end{array}$ & MacKinnon critical value \\
\hline Chitipa & $-7.669^{* * *}$ & -3.000 \\
\hline Karonga & $-6.813^{* * *}$ & -3.000 \\
\hline Rumphi & $-6.703^{* * *}$ & -3.000 \\
\hline Mzuzu & $-6.189^{* * *}$ & -3.000 \\
\hline Nkhotakota & $-5.843^{\star * *}$ & -3.000 \\
\hline Lilongwe & $6.622^{\star * \star}$ & -3.000 \\
\hline Mitundu & $-6.079^{\star * *}$ & -3.000 \\
\hline Chimbiya & $-5.924^{* * *}$ & -3.000 \\
\hline Lizulu & $-5.508^{* * *}$ & -3.000 \\
\hline Lunzu & $-5.529^{* * *}$ & -3.000 \\
\hline Luchenza & $-6.315^{\star * *}$ & -3.000 \\
\hline Bangula & $-5.551^{* * *}$ & -3.000 \\
\hline Nchalo & $-5.836^{* * *}$ & -3.000 \\
\hline Mwansambo ${ }^{+}$ & $-4.992^{\star * *}$ & -3.000 \\
\hline Chilumba $^{+}$ & $-4.621^{\star * *}$ & -3.000 \\
\hline Hewe $^{t}$ & $-5.630^{* * *}$ & -3.000 \\
\hline Mzimba & $-3.373^{* *}$ & -3.000 \\
\hline Nanjiri & $-3.101^{\star *}$ & -3.000 \\
\hline Bembeke Turn-off $^{+}$ & $-5.105^{\star * *}$ & -3.000 \\
\hline Sharpe Valley & $-4.798^{\star * *}$ & -3.000 \\
\hline Ntaja & $-3.442^{\star *}$ & -3.000 \\
\hline Zomba $^{+}$ & $-3.447^{* *}$ & -3.000 \\
\hline Limbe & $-3.018^{\star *}$ & -3.000 \\
\hline Chilinga $^{+}$ & $-5.323^{* * *}$ & -3.000 \\
\hline Nsanje $^{t}$ & $-5.510^{* * *}$ & -3.000 \\
\hline
\end{tabular}

Source: Authors' calculations based on Ministry of Agriculture and Food Security data.

Notes: Test critical values: *** Significant at $1 \%$ level, $* *$ significant at $5 \%$ level; ғ stationary in second differences, all else stationary in levels. 
Table A.3-Johansen cointegration test results

\begin{tabular}{|c|c|c|c|c|c|}
\hline \multicolumn{6}{|c|}{ Equation: Chitipa, Karonga, Rumphi, Mzuzu, ADMARC } \\
\hline $\begin{array}{l}\text { Maximum } \\
\text { rank }\end{array}$ & Parameters & LL & Eigenvalue & Trace statistic & $5 \%$ critical value \\
\hline 0 & 30 & 118.30953 & & 91.2153 & 68.52 \\
\hline 1 & 39 & 139.36946 & 0.85259 & 49.0954 & 47.21 \\
\hline 2 & 46 & 153.67258 & 0.72755 & $20.4892^{*}$ & 29.68 \\
\hline 3 & 51 & 160.44979 & 0.45996 & 6.9348 & 14.41 \\
\hline 4 & 54 & 163.84778 & 0.26575 & 0.1388 & 3.76 \\
\hline 5 & 55 & 163.91718 & 0.00629 & & \\
\hline \multicolumn{6}{|c|}{ Equation: Nkhotakota, Lilongwe, Mitundu, Chimbiya, ADMARC } \\
\hline $\begin{array}{l}\text { Maximum } \\
\text { rank }\end{array}$ & Parameters & LL & Eigenvalue & Trace statistic & $5 \%$ critical value \\
\hline 0 & 30 & 116.8162 & & 83.7839 & 68.52 \\
\hline 1 & 39 & 133.84823 & 0.78740 & 49.7198 & 47.21 \\
\hline 2 & 46 & 143.7729 & 0.59434 & 29.8705 & 29.68 \\
\hline 3 & 51 & 151.90097 & 0.52237 & $13.6143^{*}$ & 14.41 \\
\hline 4 & 54 & 158.05364 & 0.42841 & 1.3090 & 3.76 \\
\hline 5 & 55 & 158.70814 & 0.05776 & & \\
\hline \multicolumn{6}{|c|}{ Equation: Lizulu, Lunzu, Luchenza, Bangula, Chilumba, ADMARC } \\
\hline $\begin{array}{l}\text { Maximum } \\
\text { rank }\end{array}$ & Parameters & LL & Eigenvalue & Trace statistic & $5 \%$ critical value \\
\hline 0 & 42 & 256.15505 & & 143.3491 & 94.15 \\
\hline 1 & 53 & 283.997 & 0.92946 & 87.6650 & 68.52 \\
\hline 2 & 62 & 305.97451 & 0.87669 & $43.7102^{*}$ & 47.21 \\
\hline 3 & 69 & 319.98601 & 0.73669 & 15.6871 & 29.68 \\
\hline 4 & 74 & 324.59313 & 0.35517 & 6.4729 & 14.41 \\
\hline 5 & 77 & 326.33798 & 0.15310 & 2.9832 & 3.76 \\
\hline 6 & 78 & 327.82959 & 0.13243 & & \\
\hline \multicolumn{6}{|c|}{ Equation: Zomba, Limbe, Chilinga, Nsanje, ADMARC } \\
\hline \multicolumn{6}{|c|}{ Number of obs. $=21$} \\
\hline $\begin{array}{c}\text { Maximum } \\
\text { rank }\end{array}$ & Parameters & LL & Eigenvalue & Trace statistic & $5 \%$ critical value \\
\hline 0 & 30 & 150.96244 & 0.79858 & 88.5982 & 68.52 \\
\hline 1 & 39 & 167.78748 & 0.68931 & 54.9481 & 47.21 \\
\hline 2 & 46 & 180.06162 & 0.64070 & 30.3998 & 29.68 \\
\hline 3 & 51 & 190.80933 & 0.27770 & $8.9044^{*}$ & 14.41 \\
\hline 4 & 54 & 194.22515 & 0.09399 & 2.0728 & 3.76 \\
\hline 5 & 55 & 95.26153 & & & \\
\hline \multicolumn{6}{|c|}{ Equation: Hewe, Mzimba, Mchinji, Nanjiri, Bembeke, Sharpe Valley, Ntaja, ADMARC } \\
\hline $\begin{array}{l}\text { Maximum } \\
\text { rank }\end{array}$ & Parameters & LL & Eigenvalue & Trace statistic & $5 \%$ critical value \\
\hline 0 & 72 & 290.21342 & & $2,366.1492$ & 156.00 \\
\hline 1 & 87 & 672.91321 & 1.00000 & $1,600.7496$ & 124.24 \\
\hline 2 & 100 & $1,047.9884$ & 1.00000 & 850.5993 & 94.15 \\
\hline 3 & 111 & $1,389.2785$ & 1.0000 & 168.0191 & 68.52 \\
\hline 4 & 120 & $1,435.3329$ & 0.98480 & 75.9103 & 47.21 \\
\hline 5 & 127 & $1,462.2021$ & 0.91307 & $22.1718^{*}$ & 29.68 \\
\hline 6 & 132 & $1,470.5139$ & 0.53028 & 5.5483 & 15.41 \\
\hline 7 & 135 & $1,473.2548$ & 0.22056 & 0.0665 & 3.76 \\
\hline 8 & 136 & $1,473.288$ & 0.00302 & & \\
\hline
\end{tabular}

Source: Authors' calculations based on data from the Malawi Agricultural Market Information Survey

Notes: * Number of cointegrating equations; sample 1991-2012; lags = 2; number of observations $=22$ unless otherwise stated; trend: constant. 
Table A.4-Granger causality test results

\begin{tabular}{|c|c|c|c|c|}
\hline Equation & Excluded & $X^{2}$ & df & $p$ \\
\hline ADMARC & Chitipa & 3.4189 & 2 & 0.181 \\
\hline ADMARC & Karonga & 5.6817 & 2 & 0.058 \\
\hline ADMARC & Rumphi & 5.2378 & 2 & 0.073 \\
\hline ADMARC & Mzuzu & 7.0233 & 2 & 0.03 \\
\hline ADMARC & ALL & 25.989 & 8 & 0.001 \\
\hline ADMARC & Nkhotakota & 1.3672 & 2 & 0.505 \\
\hline ADMARC & Lilongwe & 3.8405 & 2 & 0.147 \\
\hline ADMARC & Mitundu & 2.9919 & 2 & 0.224 \\
\hline ADMARC & Chimbiya & 5.3937 & 2 & 0.067 \\
\hline ADMARC & ALL & 19.075 & 8 & 0.014 \\
\hline ADMARC & Lizulu & 2.8723 & 2 & 0.238 \\
\hline ADMARC & Lunzu & 6.6057 & 2 & 0.037 \\
\hline ADMARC & Luchenza & 1.7968 & 2 & 0.407 \\
\hline ADMARC & Bangula & 5.0142 & 2 & 0.082 \\
\hline ADMARC & Chilumba & 5.9674 & 2 & 0.051 \\
\hline ADMARC & ALL & 29.082 & 10 & 0.001 \\
\hline ADMARC & Hewe & 0.01399 & 2 & 0.993 \\
\hline ADMARC & Mzimba & 7.8654 & 2 & 0.02 \\
\hline ADMARC & Mchinji & 1.2879 & 2 & 0.525 \\
\hline ADMARC & Nanjiri & 7.8627 & 2 & 0.02 \\
\hline ADMARC & Bembeke Turn-off & 9.1264 & 2 & 0.01 \\
\hline ADMARC & Sharpe Valley & 15.62 & 2 & 0 \\
\hline ADMARC & Ntaja & 0.91936 & 2 & 0.631 \\
\hline ADMARC & $A L L$ & 98.451 & 14 & 0 \\
\hline ADMARC & Zomba & 23.625 & 2 & 0 \\
\hline ADMARC & Limbe & 0.08763 & 2 & 0.957 \\
\hline ADMARC & Chilinga & 11.768 & 2 & 0.003 \\
\hline ADMARC & Nsanje & 15.915 & 2 & 0 \\
\hline ADMARC & ALL & 53.687 & 8 & 0 \\
\hline
\end{tabular}

Source: Authors' calculations based on data from the Malawi Agricultural Market Information Survey 
Table A.5-Coefficient correlation test results (between local market prices)

\begin{tabular}{|c|c|c|c|c|c|c|c|c|c|c|c|c|c|c|}
\hline & Chitipa & Karonga & Rumphi & Mzuzu & Nkhotakota & Lilongwe & Mitundu & Chimbiya & Lizulu & Lunzu & Luchenza & Bangula & Mwansambo & Chilumba \\
\hline Chitipa & 1 & & & & & & & & & & & & & \\
\hline Karonga & $0.95^{\star}$ & 1 & & & & & & & & & & & & \\
\hline Rumphi & $0.91^{*}$ & $0.95^{\star}$ & 1 & & & & & & & & & & & \\
\hline Mzuzu & $0.85^{*}$ & $0.89^{*}$ & $0.89^{*}$ & 1 & & & & & & & & & & \\
\hline Nkhotakota & $0.80^{*}$ & $0.82^{*}$ & $0.86^{\star}$ & $0.91^{*}$ & 1 & & & & & & & & & \\
\hline Lilongwe & $0.72^{*}$ & $0.71^{*}$ & $0.76^{*}$ & $0.91^{*}$ & $0.88^{*}$ & 1 & & & & & & & & \\
\hline Chimbiya & $0.81^{*}$ & $0.83^{*}$ & $0.89^{*}$ & $0.92^{*}$ & $0.95^{*}$ & $0.91^{*}$ & $0.97^{*}$ & 1 & & & & & & \\
\hline Lizulu & $0.82^{*}$ & $0.86^{*}$ & $0.89^{*}$ & $0.93^{*}$ & $0.93^{*}$ & $0.86^{*}$ & $0.94^{*}$ & $0.95^{\star}$ & 1 & & & & & \\
\hline Lunzu & $0.80^{*}$ & $0.84^{*}$ & $0.79^{\star}$ & $0.77^{*}$ & $0.75^{\star}$ & $0.62^{*}$ & $0.74^{*}$ & $0.73^{*}$ & $0.84^{*}$ & 1 & & & & \\
\hline Luchenza & $0.86^{*}$ & $0.88^{*}$ & $0.88^{\star}$ & $0.95^{\star}$ & $0.93^{*}$ & $0.92^{*}$ & $0.91^{*}$ & $0.93^{*}$ & $0.92^{*}$ & $0.76^{*}$ & 1 & & & \\
\hline Bangula & $0.82^{*}$ & $0.86^{*}$ & $0.92^{*}$ & $0.83^{*}$ & $0.84^{*}$ & $0.71^{*}$ & $0.85^{\star}$ & $0.84^{*}$ & $0.90^{*}$ & $0.82^{*}$ & $0.83^{*}$ & 1 & & \\
\hline Mwansambo & $-0.46^{*}$ & -0.39 & $-0.46^{*}$ & -0.22 & -0.32 & -0.29 & $-0.49^{*}$ & $-0.45^{\star}$ & -0.37 & -0.41 & -0.37 & $-0.45^{\star}$ & 1 & \\
\hline Hewe & $-0.46^{*}$ & -0.38 & $-0.47^{*}$ & -0.22 & -0.34 & -0.30 & $-0.50^{*}$ & $-0.46^{\star}$ & -0.38 & -0.41 & -0.36 & $-0.46^{*}$ & $0.99^{*}$ & $0.99^{*}$ \\
\hline Mzimba & $-0.46^{*}$ & -0.38 & $-0.46^{*}$ & -0.22 & -0.32 & -0.29 & $-0.49^{*}$ & $-0.45^{\star}$ & -0.37 & -0.41 & -0.37 & $-0.45^{\star}$ & $0.99^{*}$ & $0.99^{*}$ \\
\hline Mchinji & $-0.44^{*}$ & -0.36 & $-0.43^{*}$ & -0.19 & -0.2993 & -0.26 & $-0.46^{*}$ & -0.39 & -0.34 & -0.3 & -0.34 & $-0.42^{\star}$ & $0.98^{*}$ & $0.96^{*}$ \\
\hline Nanjiri & $-0.44^{*}$ & -0.37 & $-0.47^{*}$ & -0.22 & -0.31 & -0.28 & $-0.4908^{*}$ & $-0.46^{*}$ & -0.37 & -0.39 & -0.34 & $-0.45^{\star}$ & $0.98^{*}$ & $0.99^{*}$ \\
\hline Bembeke & $-0.46^{\star}$ & -0.38 & $-0.46^{*}$ & -0.21 & -0.32 & -0.28 & $-0.4874^{\star}$ & $-0.44^{\star}$ & -0.37 & -0.40 & -0.35 & $-0.45^{\star}$ & $0.99^{*}$ & $0.99^{*}$ \\
\hline $\begin{array}{l}\text { Sharpe } \\
\text { Valley }\end{array}$ & $-0.45^{*}$ & -0.37 & $-0.46^{*}$ & -0.21 & -0.32 & -0.29 & $-0.4865^{\star}$ & $-0.44^{*}$ & -0.36 & -0.39 & -0.36 & $-0.44^{*}$ & $0.99^{*}$ & $0.99 *$ \\
\hline Ntaja & -0.36 & -0.29 & -0.38 & -0.11 & -0.21 & -0.17 & -0.3763 & -0.37 & -0.26 & -0.26 & -0.25 & -0.38 & $0.99^{*}$ & $0.98^{*}$ \\
\hline Zomba & -0.38 & -0.29 & -0.35 & -0.09 & -0.21 & -0.15 & -0.40 & -0.35 & -0.24 & -0.31 & -0.25 & -0.35 & $0.96^{*}$ & $0.93^{*}$ \\
\hline Limbe & $-0.41^{*}$ & -0.34 & $-0.43^{*}$ & -0.18 & -0.28 & -0.26 & $-0.46^{*}$ & $-0.42^{*}$ & -0.33 & -0.33 & -0.32 & -0.39 & $0.99^{*}$ & $0.99^{*}$ \\
\hline Chilinga & $-0.47^{*}$ & -0.39 & $-0.49^{*}$ & -0.23 & -0.34 & -0.29 & $-0.50^{*}$ & $-0.46^{*}$ & -0.39 & -0.41 & -0.36 & $-0.49^{\star}$ & $0.99^{*}$ & $0.99^{*}$ \\
\hline Nsanje & $-0.45^{\star}$ & -0.37 & $-0.46^{*}$ & -0.21 & -0.31 & -0.29 & -0.48 & $-0.45^{*}$ & -0.37 & -0.40 & -0.35 & $-0.44^{*}$ & $0.99^{*}$ & $0.99^{*}$ \\
\hline
\end{tabular}


Table A.5-Continued

\begin{tabular}{|c|c|c|c|c|c|c|c|c|c|c|c|}
\hline & Hewe & Mzimba & Mchinji & Nanjiri & Bembeke & $\begin{array}{l}\text { Sharpe } \\
\text { Valley }\end{array}$ & Ntaja & Zomba & Limbe & Chilinga & Nsanje \\
\hline Hewe & 1 & & & & & & & & & & \\
\hline Mzimba & $0.99^{*}$ & 1 & & & & & & & & & \\
\hline Mchinji & $0.98^{*}$ & $0.98^{*}$ & 1 & & & & & & & & \\
\hline Nanjiri & $0.99^{*}$ & $0.98^{*}$ & $0.95^{\star}$ & 1 & & & & & & & \\
\hline $\begin{array}{l}\text { Bembeke } \\
\text { Sharpe }\end{array}$ & $0.99^{*}$ & $0.99^{*}$ & $0.98^{*}$ & $0.98^{*}$ & 1 & & & & & & \\
\hline Valley & $0.99^{*}$ & $0.99^{\star}$ & $0.98^{*}$ & $0.98^{*}$ & $0.99^{*}$ & 1 & & & & & \\
\hline Ntaja & $0.99^{*}$ & $0.99^{*}$ & $0.96^{*}$ & $0.98^{*}$ & $0.98^{*}$ & $0.99^{*}$ & 1 & & & & \\
\hline Zomba & $0.95^{\star}$ & $0.96^{*}$ & $0.95^{\star}$ & $0.92^{*}$ & $0.95^{\star}$ & $0.96^{*}$ & $0.94^{*}$ & 1 & & & \\
\hline Limbe & $0.99^{*}$ & $0.98^{*}$ & $0.96^{*}$ & $0.98^{*}$ & $0.98^{*}$ & $0.98^{*}$ & $0.99^{*}$ & $0.94^{*}$ & 1 & & \\
\hline Chilinga & $0.99^{*}$ & $0.99^{*}$ & $0.98^{*}$ & $0.98^{*}$ & $0.99^{*}$ & $0.99^{*}$ & $0.98^{*}$ & $0.94^{*}$ & $0.98^{*}$ & 1 & \\
\hline Nsanje & $0.99^{*}$ & $0.99^{*}$ & $0.97^{*}$ & $0.99^{*}$ & $0.99^{*}$ & $0.99^{*}$ & $0.99^{*}$ & $0.95^{*}$ & $0.99^{*}$ & $0.99^{*}$ & 1 \\
\hline
\end{tabular}

Source: Authors' calculations based on Ministry of Agriculture and Food Security data.

Note: * Statistically significant at the $5 \%$ level of confidence. 


\section{APPENDIX B: HISTORICAL BACKGROUND OF ADMARC REFORMS AND IMPACTS ON VARIOUS STAKEHOLDERS IN MALAWI}

Table B.1-Historical timeline of ADMARC reforms in Malawi

\begin{tabular}{ll}
\hline Year(s) & ADMARC reform \\
\hline 1971 & $\begin{array}{l}\text { Formation of ADMARC (mandated to market agricultural inputs, produce; facilitate the development of } \\
\text { smallholder sector; and buy and sell maize in remote areas for food security) }\end{array}$ \\
1987 & $\begin{array}{l}\text { Removal of ADMARC's monopoly as sole agent responsible for importation, storage, and marketing of } \\
\text { maize; private sector allowed to engage in maize trade }\end{array}$ \\
1987 & Partial liberalization of other agricultural commodities (previously only traded by ADMARC) \\
1990 & ADMARC operating 1,300 seasonal markets, 3 regional offices, and 18 storage depots \\
1990 & ADMARC storage capacity at 468,000 mt \\
Mid-1990s & Maize price band defended by ADMARC revised/removed \\
2001 & Strategic grain reserve function of ADMARC removed and given to National Food Reserve Agency \\
2002 & ADMARC subsidiaries taken over and subsequently taken over by the Ministry of Finance \\
2002 & Disaster and emergency relief function of ADMARC moved to the Office of the President and Cabinet \\
2002 & ADMARC storage capacity reduced to 200,000 mt \\
2004 & $\begin{array}{l}\text { ADMARC operating } 300 \text { seasonal markets, } 400 \text { unit markets, } 3 \text { regional markets, and } 9 \text { storage } \\
\text { depots }\end{array}$
\end{tabular}

Source: Authors' compilation based on literature review. (Kutengule et al, 2006; Chirwa 2010a).

Several studies conducted to assess the reforms of ADMARC have shown that there were many impacts. These are summarized in Table B.2.

Table B.2-Impact of the ADMARC reforms on different stakeholders

\begin{tabular}{|c|c|c|c|}
\hline $\begin{array}{c}\text { Impact on private } \\
\text { sector }\end{array}$ & Impact on markets/prices & Impact on households & Other impacts \\
\hline $\begin{array}{l}\text { Increase in number } \\
\text { of input wholesalers } \\
\text { and retailers }\end{array}$ & $\begin{array}{l}\text { Differential increase in number } \\
\text { of input sellers (number of } \\
\text { private traders not positively } \\
\text { correlated with absence of } \\
\text { ADMARC markets) }\end{array}$ & $\begin{array}{l}\text { Reduced profitability for } \\
\text { smallholder famers due to } \\
\text { lack of organization and } \\
\text { inability to negotiate with } \\
\text { private traders }\end{array}$ & $\begin{array}{l}\text { Poor quality of business } \\
\text { practice by private traders } \\
\text { arising from lack of } \\
\text { regulation and enforcement } \\
\text { of fair trading practices }\end{array}$ \\
\hline $\begin{array}{l}\text { Increase in number } \\
\text { of crop buyers }\end{array}$ & $\begin{array}{l}\text { High price volatility within and } \\
\text { between communities, and high } \\
\text { price volatility between } \\
\text { preharvest and postharvest } \\
\text { periods, both due to lack of } \\
\text { competition }\end{array}$ & $\begin{array}{l}\text { Higher transaction and } \\
\text { transport costs for input } \\
\text { procurement as majority of } \\
\text { private traders not } \\
\text { engaged in input sales }\end{array}$ & \\
\hline $\begin{array}{l}\text { Increase in number } \\
\text { of crop wholesalers }\end{array}$ & $\begin{array}{l}\text { Interregional and interseasonal } \\
\text { arbitrage function of ADMARC } \\
\text { not successfully taken over by } \\
\text { private sector } \\
\text { Higher margins for traders, } \\
\text { lower competition and efficiency } \\
\text { in markets, and lower prices for } \\
\text { producers }\end{array}$ & $\begin{array}{l}\text { Smallholders forced to use } \\
\text { ADMARC markets in other } \\
\text { communities after closure } \\
\text { of their own depots }\end{array}$ & $\begin{array}{l}\text { Widespread claims of } \\
\text { cheating on weights and } \\
\text { measures by smallholders }\end{array}$ \\
\hline
\end{tabular}

Source: Authors' compilation based on literature review (Kutengule et al, 2006; Chirwa 2010a). 


\section{REFERENCES}

Agcaoili, M., and W. Rosegrant. 1995. "Global and Regional Food Supply, Demand and Trade Prospects to 2010." In Population and Food in the Early Twenty-First Century: Meeting Future Food Demand of an Increasing Population, edited by N. Islam, 61-84. Washington, DC: International Food Policy Research Institute.

Ahmed, V., and C. Donoghue. 2010. "Global Economic Crisis and Poverty in Pakistan.” International Journal of Micro-simulation 3 (1): 127-129.

Alantas, V., and F. Bourguignon. 2004. “The Evolution of Income Distribution during Indonesia's Fast Growth 1982-1996." In The Microeconomics of Income Distribution Dynamics in East Asia and Latin America, edited by F. Bourguignon, F. H. G. Ferreira, and N. Lustig, 175-219. Washington, DC: World Bank.

Bourguignon, F., M. Fournier, and M. Gurgan. 2001. "Fast Developments with Stable Income Distribution: Taiwan 1979-94." Review of Income and Wealth 47 (2): 139-163.

Browne, M. W., and R. Cudeck. 1992. “Alternative Tests of Assessing Model Fit.” Sociological Methods and Research 21 (2): 230-258.

Chibwana, C., M. Fisher, and G. Shively. 2012. "Cropland Allocation Effects of Agricultural Input Subsidies in Malawi." World Development 40 (1): 24-133.

Chirwa, E. W. 2005. Macroeconomic Policies and Poverty Reduction in Malawi: Can We Infer from Panel Data. Research Report. Washington, DC: The Global Development Network. www.imf.org/external/np/res/seminars/2005/macro/pdf/chirwa.pdf. . 2009. "Determinants of Marketing Channels among Smallholder Farmers in Malawi." Department of Economics Working Paper No 2009/03. Zomba, Malawi: University of Malawi. www.wadonda.com/wp2009 03.pdf.

2010a. "Assessment of Maize Trade and Market Policy Interventions in Malawi." In Food Security in Africa: Market and Trade Policy for Staple Foods in Eastern and Southern Africa, edited by A. Sarris and J. Morrison, 252-283. Glos, UK: Edward Elgar Publishing Ltd.

.2010b. Program Evaluation of Agricultural Input Subsidies in Malawi Using Treatment Effects: Methods and Practicability Based on Propensity Scores. MPRA Paper No. 21236. Munich: Munich Personal RePEc Archive. http://mpra.ub.uni-muenchen.de/21236/1/MPRA_paper_21236.pdf.

Dana, J., C. J. Gilbert, and E. Shim. 2006. "Hedging Grain Price Risk in the SADC: Case Studies of Malawi and Zambia.” Food Policy 1 (4): 357-371.

Ellis, F., and E. Manda. 2012. "Seasonal Food Crises and Policy Responses: A Narrative Account of Three Food Security Crisis in Malawi." World Development 40 (70): 1407-1417.

FAO (Food and Agriculture Organization). 2009. Policies for Effective Management of Food Price Swings in Africa: The Transmission of International Maize Price Signals in Eastern and Southern Africa. Technical Brief No. 2. Rome. www.fao.org/docs/up/easypol/829/transmission_effective mng_fd_prce swings 217en.pdf

Ferris, J. 1998. Agricultural Prices and Commodity Market Analysis. East Lansing, MI, US: Michigan State University Press.

FEWS NET (Famine Early Warning Systems Network). 2008. Import/Export Parity Price Analysis. FEWS NET Markets Guidance No 1. Washington, DC: FEWS NET. www.fews.net/docs/Publications/MT\%20Guidance_Import\%20Export\%20Parity\%20Price\%20Analysis_N o\%201_En.pdf

2010. Malawi Food Security Outlook Update. Washington, DC: FEWS NET. www.fews.net/docs/Publications/Malawi_FSOU_2010_06_final.pdf.

Fuglie, K. O., R. Suherman, and W. Adiyoga. 2002. "The Demand for Fresh and Processed Potato in Southeast Asia." In Progress in Potato and Sweet Potato Research in Indonesia: Proceedings. Edited by K. O. Fuglie, 117-129. International Potato Center / Indonesia Research Review Workshop. Bogor, Indonesia: 
Indonesian Agency for Agricultural Research and Development. www.eseap.cipotato.org/MF-ESEAP/FlLibrary/PotDemand-Keith.pdf.

Gallagher, P. 1981. The Effectiveness of Price Support Policy--Some Evidence for U.S. Corn Acreage Response, Journal of Agricultural Economics Research. 30. Quoted in Poonyth, D., P. Westhoff, A. Womack, and G. Adams. 2000. "Impacts of WTO Restrictions on Subsidized EU Sugar Exports." Agricultural Economics 22 (3): $233-245$.

Goletti, F., and S. Babu. 1994. Market Liberalization and Integration of Maize Markets in Malawi. Agricultural Economics 11 (2-3): 311-324.

Helmar, M., S. Devadoss, and W. H. Meyers. 1991. The World Feed Grains Trade Model: Specification, Estimation, and Validation. Technical Report 91-TR18. Ames, IA, US: Center for Agriculture and Rural Development. www.card.iastate.edu/publications/DBS/PDFFiles/91tr23.pdf.

IFPRI (International Food Policy Research Institute). 2009. Economic Losses and Poverty Effects of Droughts and Floods in Malawi. Malawi Strategy Support Program Brief No. 2. Lilongwe, Malawi: IFPRI. www.oerafrica.org/ResourceDownload.aspx?id=38030.

Jayne, T. S., N. Sitko, J. Ricker-Gilbert, and J. Mangisoni. 2010. Malawi Maize Marketing System. London: Department for International Development. www.aec.msu.edu/fs2/malawi/Malawi_maize markets_Report to-DFID-SOAS.pdf.

Kanyama-Phiri, G. Y. 2008. "Strategies for Land and Water Management in SADC: Experiences from Malawi." In Land and Water Management in Southern Africa: Towards Sustainable Development, edited by C. Nhiram, A. Mapiki, and P. Rankhumise, 4-18. Pretoria, South Africa: African Institute of South Africa.

Kutengule, M., A. Nucifora, and H. Zaman. 2006. "Malawi: Agricultural Development and Marketing Corporation Reforms." In Poverty and Social Impact Analysis of Reforms: Lessons and Examples from Implementation, edited by A. Coudouel, A. A. Dani, and S. Paternostro, 415-451. Washington, DC: World Bank.

Lemieux, T. 2006. "The 'Mincer Equation' Thirty Years after Schooling, Experience, and Earnings.” In Jacob Mincer: A Pioneer of Modern Labor Economics, edited by S. Grossbard, 127-145. New York: Springer Science.

Malawi, NSO (National Statistical Office). 2008. Malawi National Statistical Yearbook 2008. Zomba, Malawi. www.nsomalawi.mw/index.php?option=com_content\&view=article\&id=87\%3Astatistical-yearbook$2008 \&$ catid $=2 \&$ Itemid $=12$.

Meyer, F., J. Westhoff, J. Binfield, and J. F. Kirsten. 2006. "Model Closure and Price Formation under Switching Grain Regimes in South Africa." Agrekon 45 (4): 369-380.

Meyers, W. H., S. Devadoss, and M. Helmar. 1991. The World Soybean Trade Model: Specification, Estimation, and Validation. Technical Report 91-TR 23. Ames, IA, US: Center for Agriculture and Rural Development. www.card.iastate.edu/publications/DBS/PDFFiles/91tr23.pdf .

Minot, N. 2010. "Staple Food Prices in Malawi." Paper presented at the COMESA policy seminar "Food Price Volatility: Causes, Consequences, and Policy Options," Maputo, Mozambique, January 26.

. 2011. Transmission of World Food Price Changes to Markets in Sub-Saharan Africa. Markets, Trade and Institutions Discussion Paper No. 01059. Washington, DC: International Food Policy Research Institute.

Pearse, E., R. SriRamaratnam, and C. Daké. 1994. Dynamics of Supply and Demand for New Zealand Venison and Velvet. Wellington, New Zealand: Ministry of Agriculture and Forestry. http://maxa.maf.govt.nz/mafnet/rural-nz/profitability-and-economics/structural-change/market-dynamicsfor-venison/conf4-11.htm .

Perali, F. 2003. Partial Equilibrium Analysis of Policy Impacts (Part 1): Training Materials. Damascus, Syria: Ministry of Agriculture and Agrarian Reform. www.fao.org/world/syria/gcpita/training/materials/En/TM_Part_Eq_An_I_1-30.pdf.

Pindyck, R. S., and D. L. Rubinfeld. 1991. Econometric Models and Economic Forecasts. New York: McGraw-Hill. 
Polackek, S. W. 2007. Earnings over the Lifecycle: The Mincer Earnings Function and Its Implications. IZA DP No. 3181. Bonn, Germany: Institute for the Study of Labor. http://ftp.iza.org/dp3181.pdf.

Robilliard, A., F. Bourguignon, and S. Robinson. 2008. "Crisis and Income Distribution: A Micro-Macro Model for Indonesia." In The Impact of Macroeconomic Policies on Poverty and Income Distribution: Macro-Micro Evaluation Techniques and Tools, edited by F. Bourguignon, M. Bussolo, and L. A. Pereira da Silva, 93118. Washington, DC: World Bank.

Tewari, D. D., and K. Singh. 1996. Principles of Microeconomics. New Delhi: New Age International Publishers.

Wooldridge, J. M. 2009. Introductory Econometrics: A Modern Approach, 4th ed. Mason, OH, US: SouthernWestern Cengage Learning. 


\section{RECENT IFPRI DISCUSSION PAPERS}

\section{For earlier discussion papers, please go to www.ifpri.org/pubs/pubs.htm\#dp. All discussion papers can be downloaded free of charge.}

1253. Exchange rate policy and devaluation in Malawi. Karl Pauw, Paul Dorosh, and John Mazunda, 2013.

1252. A regional computable general equilibrium model for Honduras: Modeling exogenous shocks and policy alternatives. Samuel Morley and Valeria Piñeiro, 2013.

1251. Agricultural trade: What matters in the Doha Round? David Laborde and Will Martin, 2013.

1250. Opportunities and challenges for community involvement in public service provision in rural Guatemala. Johanna Speer and William F. Vásquez, 2013.

1249. Rising wages in Bangladesh. Xiaobo Zhang, Shahidur Rashid, Kaikaus Ahmad, Valerie Mueller, Hak Lim Lee, Solomon Lemma, Saika Belal, and Akhter Ahmed, 2013.

1248. How are farmers adapting to climate change in Vietnam?: Endogeneity and sample selection in a rice yield model. Bingxin Yu, Tingju Zhu, Clemens Breisinger, and Nguyen Manh Hai, 2013.

1247. Evaluating the local economywide impacts of irrigation projects: Feed the Future in Tanzania. Mateusz Filipski, Dale Manning, J. Edward Taylor, Xinshen Diao, and Angga Pradesha, 2013.

1246. Factor endowments, wage growth, and changing food self-sufficiency: Evidence from country-level panel data. Keijiro Otsuka, Yanyan Liu, and Futoshi Yamauchi, 2013.

1245. Impact of food price changes on household welfare in Ghana. Nicholas Minot and Reno Dewina, 2013.

1244. Parametric decomposition of the Malmquist Index in an output-oriented distance function: Productivity in Chinese agriculture. Bingxin Yu, Xiyuan Liao, and Hongfang Shen, 2013.

1243. Extreme weather and civil war in Somalia: Does drought fuel conflict through livestock price shocks? Jean-Francois Maystadt, Olivier Ecker, and Athur Mabiso, 2013.

1242. Evidence on key policies for African agricultural growth. Xinshen Diao, Adam Kennedy, Ousmane Badiane, Frances Cossar,Paul Dorosh, Olivier Ecker, Hosaena Ghebru Hagos, Derek Headey, Athur Mabiso, Tsitsi Makombe, Mehrab Malek, and Emily Schmid, 2013.

1241. A global assessment of the economic effects of export taxes. David Laborde, Carmen Estrades, and Antoine Bouët, 2013.

1240. The Women's Empowerment in Agriculture Index. Sabina Alkire, Ruth Meinzen-Dick, Amber Peterman, Agnes R. Quisumbing, Greg Seymour, and Ana Vaz, 2012.

1239. Food price volatility in Africa: Has it really increased? Nicholas Minot, 2012.

1238. The comprehensive Africa agriculture program as a collective institution. Shashidhara Kolavalli, Regina Birner, and Kathleen Flaherty, 2012.

1237. Mechanization in Ghana: Searching for sustainable service supply models. Xinshen Diao, Frances Cossar, Nazaire Houssou, Shashidhara Kolavalli, Kipo Jimah, and Patrick Aboagye, 2012.

1236. Differential export taxes along the oilseeds value chain: A partial equilibrium analysis. Antoine Bouët, Carmen Estrades, and David Laborde, 2012.

1235. The role of rural producer organizations for agricultural service provision in fragile states. Catherine Ragasa and Jennifer Golan, 2012.

1234. Cash, food, or vouchers?: Evidence from a randomized experiment in Northern Ecuador. Melissa Hidrobo, John Hoddinott, Amber Peterman, Amy Margolies, and Vanessa Moreira, 2012.

1233. Public expenditures, private incentives, and technology adoption: The economics of hybrid rice in South Asia. David J. Spielman, Deepthi Kolady, Patrick Ward, Harun-Ar-Rashid, and Kajal Gulati, 2012.

1232. Malaria and Agriculture: A global review of the literature with a focus on the application of integrated pest and vector management in East Africa and Uganda. Benjamin Wielgosz, Margaret Mangheni, Daniel Tsegai, and Claudia Ringler, 2012. 


\section{INTERNATIONAL FOOD POLICY RESEARCH INSTITUTE}

www.ifpri.org

IFPRI HEADQUARTERS

2033 K Street, NW

Washington, DC 20006-1002 USA

Tel.: +1-202-862-5600

Fax: +1-202-467-4439

Email: ifpri@cgiar.org

IFPRI LILONGWE

PO Box 31666

Lilongwe 3

Malawi

Tel.: +265-1-789747

Email: IFPRI-Lilongwe@cgiar.org 